\title{
GROUNDING THE HIGH COURT'S MODERN SECTION 92 JURISPRUDENCE: THE CASE FOR IMPROPER PURPOSE AS THE TOUCHSTONE
}

\begin{abstract}
Amelia Simpson*
\section{INTRODUCTION}

The 'free trade' provision in Australia's Constitution, section 92, remains partially uncharted territory, both as to its practical operation and its doctrinal underpinnings. Section 92 is presently understood as a non-discrimination norm. While interpretation has cleaved the norm into two distinct strands, this article addresses only one of those, that concerning protectionist discrimination against interstate trade or commerce. Although there are many outstanding issues regarding this norm's operation in particular settings - for instance its operation upon the Commonwealth and its ramifications for export controls ${ }^{1}$ - I will not be exploring those frontiers here. Rather, my interest is in the established core of the protectionist discrimination principle and the soundness of its doctrinal underpinnings. I will focus in this article upon a crucial missing piece in our contemporary picture of section 92's make up, specifically, the relationship between legislative purpose and practical effect in the identification of protectionist discrimination. $^{2}$
\end{abstract}

* Lecturer, Faculty of Law, ANU. For helpful comments and suggestions on earlier drafts the author thanks Karl Alderson, Jamison Colburn, Michael Dorf, Kent Greenawalt, Graeme Hill, Leighton McDonald, Sir Anthony Mason, Gerald Neuman, James Stellios, Leslie Zines and the Federal Law Review's anonymous referees. This article forms part of the author's JSD dissertation at Columbia University School of Law.

1 A survey of the section 92 scholarship since Cole $v$ Whitfield reveals many questions awaiting clarification by the Court. See, eg, Michael Coper, 'Section 92 of the Australian Constitution since Cole $v$ Whitfield' in H P Lee and George Winterton (eds), Australian Constitutional Perspectives (1992) 129; Leslie Zines, The High Court and the Constitution (4th ed, 1997) ch 8; Dennis Rose, 'Cole v Whitfield: 'Absolutely Free' Trade?' in H P Lee and George Winterton (eds), Australian Constitutional Landmarks (2003); David Sonter, 'Intention or Effect? Commonwealth and State Legislation after Cole v Whitfield' (1995) 69 Australian Law Journal 332.

2 Needless to say, dealing with this question in isolation is a somewhat artificial undertaking, as it is not easily disentangled from the Court's approach to other constitutional limitations or from its views on purpose-based and effects-based tests and criteria more generally. Readers should keep in mind that the issues raised and arguments made in this article may have wider ramifications and, likewise, may be affected by trends and shifts manifesting elsewhere in the High Court's jurisprudence. 
The article comprises four sections. Section 1 revisits recent section 92 cases and explains how these have significantly, though not completely, demystified section 92's operation as regards interstate trade. Sections 2 and 3 examine two existing, alternative, accounts concerning the precise composition of the High Court's protectionist discrimination test, focusing particularly on the role attributed to legislative purpose. The first account, dealt with in Section 2, is a descriptive account asserting that improper legislative purpose is the primary touchstone by which protectionist discrimination is identified, its presence being a necessary condition for section 92's operation. I find that account inadequate for its lack of a firm grounding in the case law. Section 3 turns to a second existing account, framed by reference to a principle of 'proportionality'. This account views improper purpose as a sufficient rather than a necessary condition for section 92's operation. It infers a balancing approach, grounded ultimately in a conception of the section 92 norm as defeasible, and defends this understanding as appropriate. Ultimately, I find this explanation unconvincing as its central assumptions about the norm's structure do not find clear confirmation in the cases. In Section 4 I offer my own prescriptive view. I there explore several considerations that should guide the Court in selecting, and cementing, the doctrinal foundations of its modern section 92 jurisprudence. I suggest that these considerations - section 92's federal rationale, wider concerns about defeasibility in federal structural provisions, and the limits of the High Court's capacities and competencies - favour a conception of protectionist discrimination that places legislative purpose at its centre.

To some minds the relative significance of, and relationship between, purpose and effect in section 92 jurisprudence may seem insignificant, in that clarification would seem to make little practical difference to the norm's application. I concede readily that the alternative conceptions of section 92 canvassed in this article would not often generate different results when applied to concrete cases. Rather, their main significance lies in their capacity to serve as secure anchors for the modern section 92 jurisprudence - at the level, in other words, of doctrinal rationalisation. Given section 92's history, fraught with disagreement and instability, the legitimacy and longevity of the present approach will depend upon its having thoroughly worked out an acceptable philosophical foundation. For so long as it remains, on this score, an unfinished project, the modern section 92 jurisprudence is particularly vulnerable to the corrosive forces of doubt and indecision.

Aside from bringing this greater resilience to the doctrine, the clarification that I am proposing would have other pay-offs. From the point of view of litigants, the existing unclear relationship between legislative purpose and practical effect, in terms of triggering section 92's operation, leaves uncertainty as to the kind of case they must make. With a clearer idea as to how, precisely, the Court uses the evidence put before it litigants could present their cases more effectively and efficiently. Further, litigants and judges alike would, with the clarification proposed, be in a better position to assess the comparability and relevance of decisions and doctrines drawn from other constitutional systems. ${ }^{3}$

3 In particular, the High Court's equivocation regarding the relevance of United States 'dormant commerce clause' jurisprudence may be traced, at least in part, to the ambiguity still lurking within its approach to section 92 . The viability of comparisons with the free 


\section{SECTION 92 AS A NON-DISCRIMINATION NORM}

Section 92, the guarantee of free interstate trade, provides in operative part:

trade, commerce, and intercourse among the States, whether by means of internal carriage or ocean navigation, shall be absolutely free.

As already mentioned, this article considers the provision only as it applies to trade and commerce. The High Court has indicated that the principles governing 'intercourse' are relevantly distinct. ${ }^{4}$

After many decades of disagreement, the Court has in relatively recent times cemented section 92's status as a non-discrimination norm. This Section explores the contours of that norm as they emerge from the two most commonly discussed recent cases, Cole v Whitfield ${ }^{5}$ and Castlemaine Tooheys Ltd v South Australia. ${ }^{6}$

When identifying and analysing the features of a non-discrimination norm, it can be helpful to think in terms of the norm's outer limits and the principles that sustain those limits. Every non-discrimination norm contains some limitations upon its reach. No legal system could hope to, or would want to, maintain a principle of nondiscrimination that was entirely unconfined. History and moral intuition alike confirm that eliminating differences and their attendant inequalities altogether is an impossible task. ${ }^{7}$ Further, as most people involved or interested in law-making would now agree, differentiation which leaves some people better off may produce desirable consequences in some settings. The challenge for lawmakers is to construct nondiscrimination norms that have sufficient bite while at the same time guarding against unpalatable overreach. The legal principles that define, and guide the identification of, discrimination in a particular setting furnish these all important outer limits.

In this ongoing process of developing and refining non-discrimination norms, most lawmakers, including courts, have at some point conceded the inadequacy of legal form as a touchstone with which to delimit a norm's reach. In Australia's constitutional non-discrimination jurisprudence, the abandonment of tests focusing upon legal form took considerably longer than in many other constitutional systems. Yet even as a late

trade jurisprudence of the European Community and the World Trade Organization will likewise remain unclear until section 92's doctrinal contours are clarified.

4 Cole v Whitfield (1988) 165 CLR 360, 388. Since Cole there has been some attention given to the 'intercourse' limb of s 92, most recently in APLA Ltd v Legal Services Commissioner (NSW) (2005) 219 ALR 403 ('APLA'). There, three members of the Court endorsed the idea that intercourse is a separate limb of s 92, governed by different principles (Gleeson CJ and Heydon J at 415 [38], Gummow J at 445 [162]). One doubted the utility of the distinction but accepted its authority (Hayne J at 502 [402], 507 [426]). Another seemed to deny the distinction altogether (Callinan J at 522-3 [462]-[464]). Justices McHugh and Kirby did not need to address the $\mathrm{s} 92$ issue.

(1988) 165 CLR 360.

(1990) 169 CLR 436 ('Castlemaine').

See, eg, Isaiah Berlin, 'Equality as an Ideal' in Frederick Olafson (ed), Justice and Social Policy (1961) 129-30, 137, 141; Joseph Raz, The Morality of Freedom (1986) 234-35; Michael Walzer, Spheres of Justice (1983) xii; Peter Singer, Practical Ethics (2nd ed, 1993) 25. 
follower of other trailblazing courts, ${ }^{8}$ the High Court's journey has not been free from confusion and indecision.

While I will be arguing that the section 92 test requires further clarification, I do not underestimate the considerable advances in clarity achieved in the Court's most recent decisions. Until the Mason Court's radical surgery upon section 92, to be discussed shortly, section 92 was one of the Australian Constitution's most notoriously problematic provisions, due in no small part to its enigmatic text. ${ }^{9}$ A number of competing approaches had vied for dominance over the years with no single approach ever enjoying solid and enduring consensus. ${ }^{10}$ Deepest among these disagreements was the gulf between 'free trade' perspectives, on the one hand, and 'individual rights' perspectives, on the other. Advocates of the former view saw section 92 as concerned with protectionist discrimination, often according to a formalistic understanding. ${ }^{11}$ Those favouring the individual rights approach viewed section 92 principally as a guarantee of individuals' freedom to trade across State borders, typically focusing on substance over form. ${ }^{12}$ On the rights-focused approach, notions of discrimination and protectionism took a back seat.

Solid and enduring consensus on section 92 eluded the High Court until its watershed decision in 1988 in Cole $v$ Whitfield.

\section{(i) Cole $v$ Whitfield}

The Court's landmark decision in Cole $v$ Whitfield largely swept away the jumble of preexisting case law. It anointed an interpretation which views section 92 as a prohibition on 'discriminatory burdens of a protectionist kind'. ${ }^{13}$ Readers are likely to be familiar with the relevant facts and the arguments put, so I will not recount them here.

The Solicitors-General for the Commonwealth and all the States joined forces in urging the Court to abandon the individual rights understanding of section 92 and instead adopt protectionism as its focus. ${ }^{14}$ In a unanimous judgment the Court did just that. It opted to take original intent as its compass in navigating the section 92 minefield, finding that while the text offered negligible interpretative guidance, ${ }^{15}$ the

8 In particular, the Court has referred to discrimination jurisprudence in United States, Canadian, and European courts in the course of developing its own approach. See, in particular, Street v Queensland Bar Association (1989) 168 CLR 461.

9 It has been said that 'the vague terminology of section 92 [indicates] that its drafters intended its scope to be determined by judicial interpretation': Gerard Carney, 'The Reinterpretation of Section 92: The Decline of Free Enterprise and the Rise of Free Trade' (1991) 3 Bond Law Review 149, 149.

10 For discussion of these shifting positions, see Michael Coper, Freedom of Interstate Trade under the Australian Constitution (1983); Zines, above n 1, chs 6-7; Geoffrey Sawer, Australian Federalism in the Courts (1967) ch 10.

11 See, eg, Evatt J's conception of s 92, as outlined in $R v$ Vizzard; Ex parte Hill (1933) 50 CLR 30, 71; See also Murphy J's 'fiscal burden theory', which focused upon discrimination although within the otherwise limited domain of fiscal burdens: Buck v Bavone (1976) 135 CLR 110, 132.

12 See, in particular, Barwick CJ in Samuels v Readers' Digest Association Pty Ltd (1969) 120 CLR 1, 14-15. See also Dixon J's understanding of s 92, for instance in O Gilpin Ltd v Commissioner for Road Transport \& Tramways (NSW) (1935) 52 CLR 189, 205-6.

13 (1988) 165 CLR 360, 394.

14 Ibid 379

15 Ibid 385 
provision's history ${ }^{16}$ lent strong support to an interpretation focused on discriminatory burdens of a protectionist kind. In the course of developing this view, the Court acknowledged the problems attending an 'individual rights' conception of section 92. That approach, the Court said, had too often functioned to immunise interstate trade from regulatory measures to which local trade remained subject, giving rise to an illogical preferential treatment for the former. ${ }^{17}$ Moreover, the individual rights approach had failed to recognise that regulatory measures, restrictive of trade generally, were often necessary and appropriate. ${ }^{18}$

Based on the Convention Debates and other key historical materials the Court found that, at least as regards trade and commerce, section 92's evident purpose was to 'create a free trade area throughout the Commonwealth'. ${ }^{19}$ Importantly, though, the Court understood 'free trade' in terms of an absence not of regulation but rather discrimination. In economic terms, the intended target of section 92 was seen to be protectionism, meaning simply 'the protection of domestic industries against foreign competition.' ${ }^{20}$ The Cole Court accepted, as others had before it, that protectionism was a policy pursued essentially through rules effecting discrimination. ${ }^{21}$

Importantly, the Cole Court insisted that section 92 proscribes both direct and indirect protectionist discrimination:

The concept of discrimination in its application to interstate trade and commerce necessarily embraces factual discrimination as well as legal operation. A law will discriminate against interstate trade or commerce if the law on its face subjects that trade or commerce to a disability or disadvantage or if the factual operation of the law produces such a result. 22

Where dealing with questions of factual operation, as potentially revealing instances of indirect or substantive protectionist discrimination, the Court thought that its inquiry should proceed as follows:

if a law, which may be otherwise justified by reference to an object which is not protectionist, discriminates against interstate trade or commerce in pursuit of that object in a way or to an extent which warrants characterization of the law as protectionist, a court will be justified in concluding that it nonetheless offends section 92.23

Recognising that the possible methods for pursuing protectionist objectives are many and varied, the Court conceded that the application of this test would often give rise to difficult factual questions, typically turning on political and economic considerations rather than legal ones. ${ }^{24}$ Still, it was content to leave those potential problems for future resolution.

16 Notably, Cole $v$ Whitfield was the first High Court decision to give majority approval to use of the Convention Debates as an interpretative aid.

Cole $v$ Whitfield (1988) 165 CLR 360, 402-3.

18 Ibid 403.

19 Ibid 391. The Court indicated that it saw no need to enunciate a single set of principles to govern all three subjects of s 92 - trade, commerce, and intercourse. Different principles might govern s 92's operation where intercourse was concerned: at 388, 394.

20 Ibid 392-3.

21 Ibid 391-2

22 Ibid 399.

23 Ibid 408.

24 Ibid 408-9. 
As to the case at hand, the Court found that while the impugned rules were 'unquestionably a burden' on interstate trade in crayfish, they did not generate a 'competitive or market advantage' for the local trade. ${ }^{25}$ In making these findings, the Court accepted at face value key assertions contained within the parties' agreed statement of facts, including as to the claimed impracticality of alternatives to the law's blanket prohibition. ${ }^{26}$ Some commentators have since suggested that these 'facts' were incomplete and contestable, making for a dubious foundation for the decision. ${ }^{27}$ However, while the Court might be accused of glossing over the potential problems with the agreed facts in this case, it certainly did not attempt to conceal the wider doctrinal dilemma, acknowledging openly that in this realm it was dealing with 'questions of fact and degree on which minds might legitimately differ.' ${ }^{28}$

\section{(ii) Castlemaine Tooheys Ltd $v$ South Australia}

Following Cole $v$ Whitfield, the Court has addressed the trade and commerce aspect of section 92 comprehensively in only three cases. ${ }^{29}$ Of these, the most illuminating as to the relationship between purpose and effect is Castlemaine. ${ }^{30}$ Again, the facts and key arguments are likely familiar to readers and need not be repeated here.

Like Cole $v$ Whitfield the case was one of indirect discrimination, if anything, in that the impugned rules were all meticulously uniform as a matter of legal form. ${ }^{31}$ While a burdensome differential effect upon the Plaintiffs was not disputed, the parties disagreed as to whether that burden revealed discrimination of a protectionist kind. The pressing question was framed as follows:

how should the Court approach the determination of the validity of State legislation which attempts on its face to solve pressing social problems by imposing a solution which disadvantages the trade in beer brewed outside the State as against the trade in beer brewed within the State? ${ }^{32}$

The Court was unanimous in finding that several of the impugned provisions were discriminatory in a protectionist sense and so invalid. The leading judgment of Mason CJ, Brennan, Deane, Dawson and Toohey JJ concluded that a burden which 'appears to be directed to the solution of social and economic problems ... [may be found] nondiscriminatory in the relevant sense on that account'. 33 Specifically, section 92 would not be infringed by rules that (1) were 'appropriate and adapted' to the pursuit of policy objectives other than protectionism and (2) burdened interstate trade in a manner 'incidental and not disproportionate' to the pursuit of those objectives. ${ }^{34} \mathrm{By}$

25 Ibid 409.

26 Ibid 382-3, 409-10.

27 See, eg, Zines, above n 1, 140; Michael Coper, 'Section 92 and the Future of Agricultural Marketing', Address to the Agricultural Economics Society (Victorian Branch), 13 October 1988, 23.

28 Cole v Whitfield (1988) 165 CLR 360, 409.

29 Bath v Alston Holdings Pty Ltd (1988) 165 CLR 411; Castlemaine (1990) 169 CLR 436; Barley Marketing Board (NSW) v Norman (1990) 171 CLR 182 ('Barley Marketing Board').

30 (1990) 169 CLR 436.

31 However, the Ministerial Notice exempting refillable bottles from the refund and collection provisions of the new legislative regime was clearly not uniform in its application: ibid 462 (Mason CJ, Brennan, Deane, Dawson and Toohey JJ).

32 Ibid 472.

33 Ibid.

34 Ibid 473. 
reference to this test the leading judgment found key elements of South Australia's regulatory regime to transgress section $92 .{ }^{35}$

Justices Gaudron and McHugh delivered a separate joint judgment. For now, it is sufficient to note that they, too, found that key aspects of the South Australian regulatory regime fell foul of section 92 's prohibition. ${ }^{36}$

\section{(iii) The elusive missing element}

While not resolving every issue surrounding the construction of section 92, the modern jurisprudence elaborated in Cole and subsequent cases has cleared up at least two things. First, the Court has accepted that section 92 is a proscription of protectionist discrimination rather than a guarantee of an individual right to trade across borders. ${ }^{37}$ Second, the Court has confirmed that protectionist discrimination need not appear on the face of a law in order to offend section 92 - substantive or indirect protectionist discrimination might also be caught. ${ }^{38}$ These points are central to how the Court now understands the section 92 norm. Nevertheless, those pieces are not alone sufficient to complete the picture. As I foreshadowed at the outset, as to one further critical marker of section 92's outer limits the Court has yet to commit clearly as between two plausible alternative views.

The first of these alternatives assumes a touchstone of improper legislative purpose, $^{39}$ whereby section 92 would only operate to defeat laws motivated by a purpose of protectionist discrimination. The second is best understood, I think, as an effects-focused principle kept in check by a proviso of defeasibility. If this were on foot, it would mean that the section 92 norm would extend, in principle, to prohibit unintended protectionist discrimination. However, crucially, the price of this extended scope would be to render the norm defeasible, that is, subject to override where competing social interests seemed to trump it. Both alternatives represent ways of confining the reach of section 92 within acceptable limits and one or the other is evidently at work within the modern section 92 jurisprudence. The remaining Sections are devoted to a closer examination of these alternatives - their plausibility, on a descriptive level, and their appeal, on a prescriptive level.

This examination is, as it happens, timely. The High Court's latest encounter with section 92 suggests that it may soon be ready to launch into this uncharted territory. In

Ibid 477.

Ibid 479-80.

Cole v Whitfield (1988) 165 CLR 360, 394-5, 402-3; Barley Marketing Board (1990) 171 CLR 182, 201.

38 Cole v Whitfield (1988) 165 CLR 360, 394, 399; Castlemaine (1990) 169 CLR 436, 472, 478.

39 In cases where protectionist discrimination follows not from legislation but rather from an administrative decision made under legislation, an analogous criterion of improper executive purpose can be employed to identify breaches of section 92. Although this was recognised as an issue from very early on, the High Court has in recent times expressed confidence in the capacity of modern administrative law doctrines to deal effectively with such situations: Miller v TCN Channel Nine Pty Ltd (1986) 161 CLR 556, 570, 614, 619. Nevertheless, some commentators doubt that the problem of discrimination through administrative discretion can be dismissed so readily: see, eg, Zines, above n 1, 134-5, 1467. For an example of how administrative arrangements may by relevant to the application of the Cole test, see Cross v Barnes Towing and Salvage (Qld) Pty Ltd [2005] NSWCA 273, (Unreported, Spigelman CJ, Handley and Beazley JJA, 8 August 2005) [56]. 
APLA $A^{40}$ the Court considered the intercourse limb of section 92 and, specifically, how analysis should proceed in cases where some regulated activity is arguably both intercourse and trade or commerce. In addressing this issue, two members of the Court seemed to assume that the trade and commerce limb of section 92 turned on improper legislative purpose, thus having no application at all to instances of unintended protectionist effect. ${ }^{41}$ Other members of the Court carefully avoided venturing into discussion of the trade and commerce limb, emphasising that there was no evidence of any protectionist discrimination. ${ }^{42}$ Nevertheless, the extensive and rather provocative treatment given to the broader section 92 doctrine in Hayne J's judgment places the relationship between purpose and effect squarely on the table for future resolution. ${ }^{43}$

Before turning to examine the alternatives outlined above, I should provide an alternate statement of my thesis that highlights its consequences for one prevalent view of the structure of modern s 92 analysis. It is sometimes suggested that modern section 92 analysis can be reduced to a decision tree, or series of sequential steps, along the following lines: ${ }^{44}$

Qn 1: Does the impugned law discriminate, in form or effect, against interstate trade? If yes;

Qn 2: Does it have a protectionist purpose or effect? If yes;

Qn 3: Is the law nevertheless permissible as a regulatory measure, in that it is appropriate and adapted to the pursuit of a legitimate (non-protectionist) policy goal?

The cabining of policy considerations at stage three in this suggested sequence may seem particularly intuitive to commentators familiar with earlier modes of section 92 analysis, under which issues of 'regulation' and its acceptable limits were treated as a distinct and supervening inquiry.

Viewed through this lens, my contention is really that Cole $v$ Whitfield and subsequent cases do not clearly support this formulation of the section 92 test. Specifically, the suggested test assumes that section 92 extends to instances of unintentional protectionist discrimination and, further, that other policy goals and social interests are relevant because they may outweigh the interest in nondiscrimination. This reflects the effects-plus-defeasibility idea sketched above, to be discussed in Section 3 of this article as the essential philosophy underpinning a 'proportionality' approach to section 92. However, as already mentioned, I think the cases are equally consistent with an ultimate touchstone of legislative purpose. On this view, to be addressed in Sections 2 and 4, policy considerations and the appropriateness of legislated responses are relevant because they are indicia of

(2005) 219 ALR 403.

Ibid 505-7 [416], [422] (Hayne J); 522-3 [462]-[463] (Callinan J).

Ibid 414 [36] (Gleeson CJ and Heydon J); 447 [168] (Gummow J).

Ibid 502-7 [401]-[426].

This particular variation was proposed by an anonymous referee of this article. A similar formulation is given by Melissa Castan and Sarah Joseph, Federal Constitutional Law: A Contemporary View (2001) 270. Other formulations collapse stages 1 and 2, producing a twostage inquiry in which the first stage identifies prima facie breach while the second considers any exculpatory regulatory goals. See, eg, Zines, above n 1, 151-2; Jeremy Kirk, 'Constitutional Guarantees, Characterisation and the Concept of Proportionality' (1997) 21 Melbourne University Law Review 1, 15. 
legislative purpose. If this latter view of section 92 is to be preferred, as I will suggest it should be, the three step decision tree approach outlined above is inappropriate. This is because it treats improper purpose only as a sufficient, rather than a necessary, element in triggering section 92 's operation. Thus, in rejecting a proportionality approach to understanding and applying section $92 \mathrm{I}$ am necessarily rejecting the three step decision tree model also.

\section{DO THE CASES TREAT IMPROPER PURPOSE AS A NECESSARY ELEMENT?}

The view that section 92's prohibition turns on legislative purpose - that is, that a protectionist purpose is a necessary condition for a finding that section 92 has been transgressed - is not a new one. This same idea underpinned one of the competing approaches that had vied for ascendency in the decades prior to Cole $v$ Whitfield. ${ }^{45} \mathrm{~A}$ modern version of this view, developed by David Sonter, relies upon a series of passages extracted from the modern section 92 cases. ${ }^{46}$ Based on these passages Sonter asserts that the Court's inquiry is geared, implicitly, to exposing and adjudging legislative purpose. This Section assesses the appeal of his claim.

Sonter assumes that the Court's modern section 92 jurisprudence treats discrimination and protectionism as distinct elements, to be proved separately. ${ }^{47}$ While he concedes that the identification of discrimination turns on a law's form or effects only, he contends that the element of protectionism turns instead on a showing of improper purpose.

As Sonter explains, Cole $v$ Whitfield contains several passages suggestive of an intrinsic concern with legislative purpose. ${ }^{48}$ In not finding explicit protectionist discrimination, the Cole Court thought it conclusive that 'no discriminatory protectionist purpose appears on the face of the [impugned] law.'49 As to indirect protectionist discrimination, the Court had already indicated its support for the general proposition that:

A law which has as its real object the prescription of a standard for a product or a service or a norm of commercial conduct will not ordinarily be grounded in protectionism and will not be prohibited by section $92 .{ }^{50}$

The probative value of this passage is obviously lessened by the qualifier 'ordinarily'. In any case, applying the general proposition the Court found that the Tasmanian law's 'object ... is to assist in the protection and conservation of an important and valuable natural resource', 51 militating against a finding of protectionist discrimination.

As Sonter concedes, though, other passages in Cole $v$ Whitfield might be held up as instead signifying a principal concern with effects in the identification of

45 The approach is usually traced to Evatt J's leading judgment in $R v$ Vizzard; Ex parte Hill (1933) 50 CLR 30, 71. See Zines, above n 1, 112-3; Sawer, above n 10, 182-3.

Sonter, above n 1, 337-41.

Ibid 347.

Ibid 337.

(1988) 165 CLR 360, 409.

Ibid 408 .

Ibid 409. 
protectionism. ${ }^{52}$ In particular, in defending its decision to give section 92 a 'free trade' orientation, the Court said this about section 92's anti-protectionist object:

The means by which that object is achieved is the prohibition of measures which burden interstate trade and commerce and which also have the effect of conferring protection on intrastate trade and commerce of the same kind. The general hallmark of measures which contravene s 92 in this way is their effect as discriminatory against interstate trade and commerce in that protectionist sense. 53

Concern with effects also appears in various passages emphasising the pivotal role of fact-finding. The Court acknowledged:

The means by which domestic industry or trade can be advantaged or protected are legion. The consequence is that there will always be scope for difficult questions of fact

These factual inquiries, the Court said, typically would be 'political, social or economic' in nature rather than legal. ${ }^{55}$ The importance of effects is also evident in the Court's reference to the characterisation process:

if a law, which may be otherwise justified by reference to an object which is not protectionist, discriminates against interstate trade or commerce in pursuit of that object in a way or to an extent which warrants characterization of the law as protectionist, a court will be justified in concluding that it nonetheless offends s 92.56

Sonter is right to assert that these passages, while confirming that a rule's effects matter to a determination of protectionism, do not go so far as to commit the Court to an intrinsic interest in those effects. Nevertheless, they do seem to render the decision as a whole inconclusive as to the precise significance of effects. Sonter does not see this ambiguity as undermining his descriptive thesis. Yet where he sees evidence of an ultimate touchstone of purpose, others would likely perceive only an inconclusive selection of passages to be called in aid either for or against the purpose thesis.

Moreover, a balanced account would not likely see subsequent cases as clarifying things. Sonter, however, finds in Castlemaine further confirmation that the Court does, as a matter of fact, treat protectionist purpose as a necessary element of protectionist discrimination. He places particular emphasis upon several passages in the leading judgment, in particular:

where a law on its face is apt to secure a legitimate object but its effect is to impose a discriminatory burden upon interstate trade as against intrastate trade, the existence of a reasonable non-discriminatory alternative means of securing the legitimate object suggests that the purpose of the law is ... to effect a form of prohibited discrimination. There is also some room for a comparison, if not a balancing, of means and objects in the context of s 92. The fact that a law imposes a burden upon interstate trade and commerce that is not incidental or that is disproportionate to the attainment of the legitimate object of the law may show that the true purpose of the law is not to attain that object but to impose the impermissible burden. 57

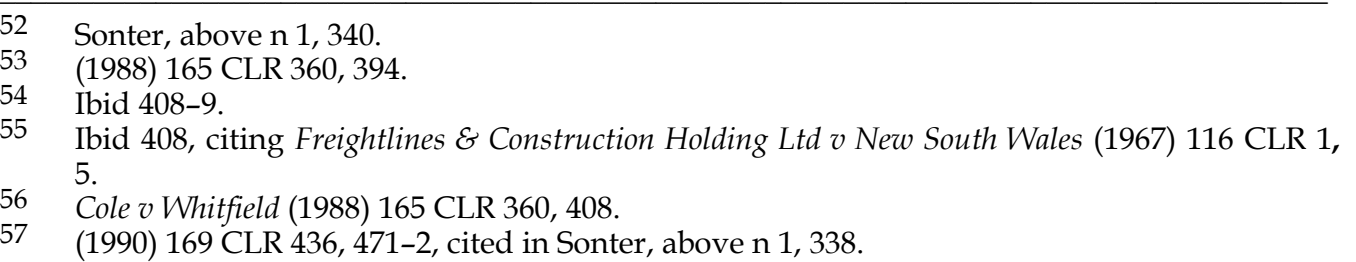


This passage indeed demonstrates that the impugned provisions' apparent purpose, as divined from their effects, influenced the Court's determination in Castlemaine. Crucially, though, this and other passages upon which Sonter relies do not demonstrate that a showing of protectionist purpose is a necessary element of protectionist discrimination. They merely demonstrate that it may be sufficient to ground such a finding. As we shall see in Section 3, the latter position is entirely consistent with a proportionality explanation of section 92 jurisprudence as well.

Other passages in Castlemaine, overlooked by Sonter, indeed might suggest that an improper purpose is not a necessary condition for invalidity. In particular:

If the South Australian legislation were not attempting to provide a solution to [environmental and litter] problems, the burden on interstate trade would be discriminatory in a protectionist sense because its operation would be discriminatory and protectionist in effect, even though the legislation on its face would treat interstate and intrastate trade evenhandedly. ${ }^{58}$

This seems more to suggest that the unintended effects of an impugned law may provide sufficient grounds for a finding of protectionist discrimination. The leading judgment then proceeds to consider whether and how the putative regulatory objectives alter the calculus.

Sonter certainly succeeds in demonstrating that legislative purpose is one important consideration feeding into section 92's operation. However, his assembled evidence falls short of demonstrating that a law cannot fall foul of section 92 in the absence of a protectionist purpose. He may have demonstrated sufficiency - that all discriminatory laws exhibiting a protectionist purpose will transgress the prohibition. However, merely to show that does not distinguish his position usefully from the rival proportionality view to be discussed in Section 3.

As a descriptive project, Sonter's analysis is less convincing than the proportionality thesis to be examined in Section 3. It is also less intrinsically appealing than the apparent intuitions of other commentators that the Court has yet to reach agreement upon the detailed contours of the modern section 92 test. ${ }^{59}$ Interestingly, Sonter does not attempt to bolster his descriptive thesis with an argument that a focus upon legislative purpose is actually preferable. Had he done so, he would have been on stronger ground. On an analysis limited to description, the only sensible conclusion is that the section 92 decisions are too internally contradictory to permit of conclusive inference.

\section{DO THE CASES CONFIRM A ROBUST PROPORTIONALITY APPROACH?}

A second account of modern section 92 jurisprudence understands it to encompass a 'proportionality' doctrine, in which improper purpose serves as a sufficient, though not a necessary, condition for section 92's operation. While many commentators have assumed the prevailing approach to incorporate some kind of evaluative balancing

58 Castlemaine (1990) 169 CLR 436, 472

59 See Coper, 'Section 92 of the Australian Constitution', above n 1, 141; Zines, above n 1, 4467. That the present Court harbours significant disagreement regarding section 92's doctrinal contours is evident in APLA (2005) 219 ALR 403. 
process $^{60}$ few have attempted a detailed explanation and defence of that viewpoint. Among the most thorough and carefully reasoned accounts is that provided by Jeremy Kirk in the course of a broader exploration of proportionality's place in Australian constitutional jurisprudence. ${ }^{61}$ As Kirk puts the case at its highest I will in this Section focus on his account, in so far as it is descriptive. Proportionality's appeal on a prescriptive level will be discussed in Section 4.

Kirk contends that the High Court has, in various constitutional contexts, introduced a concept of proportionality inspired by the three-level doctrine prevalent in European Courts. ${ }^{62} \mathrm{He}$ cites section 92 jurisprudence as one context in which proportionality analysis is deeply embedded; there, the embrace of the European model of proportionality would be complete if the Court were explicit about the threelevel nature of the analysis. ${ }^{63}$

Under the European model of proportionality, the three levels of analysis are sequential and cumulative. Only laws satisfying all three requirements - 'suitability', 'necessity' and 'balancing' - will be found valid. In its totality, this analysis is geared to determining whether a law restricting some 'protected interest' should stand in spite of that restriction. ${ }^{64}$ Assessment of a law's 'suitability' involves asking whether it is an 'effective, appropriate or rational means of achieving the claimed end.'65 Only if the law could plausibly be directed to a legitimate end - generally anything other than a desire to restrict the protected interest - will a law satisfy the first-level suitability requirement. The second-level consideration of 'necessity' turns on whether some alternative, less restrictive, means of pursuing the law's legitimate purpose was reasonably available. ${ }^{66}$ Only laws adopting the least restrictive means to their particular ends will satisfy the necessity requirement. The third level of proportionality analysis, 'balancing', represents the true essence of the approach and for that reason is sometimes termed proportionality 'in the narrow sense' or 'in the strict sense'. ${ }^{67}$ It involves an administering court in a cost-benefit analysis, requiring it to weigh the relative importance of the protected interest, on the one hand, and the legitimate goal to which an impugned law is directed, on the other. ${ }^{68}$ Only if the court agrees that an impugned law strikes a reasonable and justifiable balance will the third-level balancing requirement be met. In this sense, the third-level balancing requirement is, on the

60 See, eg, Susan Kenny, 'Constitutional Fact Ascertainment' (1990) 1 Public Law Review 134, 136; Christopher Staker, 'Section 92 of the Constitution and the European Court of Justice' (1990) 19 Federal Law. Review 322, 335; Zines, above n 1, 140-3, 446-7; Carney, above n 9, 161; Gonzalo Villalta Puig, 'Free Movement of Goods: The European Experience in the Australian Context' (2001) 75 Australian Law Journal 639, 647.

61 Kirk, above $\mathrm{n} 44$.

62 Kirk notes that the same 'sophisticated model' of proportionality has been adopted in the constitutional rights jurisprudence of Canada and Hong Kong: ibid 4. The South African Constitutional Court has also embraced that model: see $S v$ Makwanyane, 1995 (6) BCLR 665 (CC).

63 Kirk, above n 44, 12-16.

64 Or be accepted as 'compatible' in those contexts where reviewing courts are limited to processes of 'soft review'.

65 Kirk, above n 44, 6.

66 Ibid 7-8.

67 Jürgen Schwartze, European Administrative Law (1992) 687; Nicholas Emiliou, The Principle of Proportionality in European Law: A Comparative Study (1996).

68 Kirk, above n 44, 8-9. 
European model, more pronouncedly evaluative than the preceding levels of analysis, requiring as it does that courts second guess a legislature's choices and preferences among competing values and interests. ${ }^{69}$

In the constitutional guarantee context, it is useful to distinguish between the largely deductive, non-evaluative, reasoning embodied in the first- and second-level inquiries into suitability and necessity, on the one hand, and the evaluative reasoning invited by the third-level balancing inquiry, on the other. ${ }^{70}$ Kirk's account of European-style three-level proportionality analysis accepts and utilises this distinction. ${ }^{71}$

As Kirk's account acknowledges, Australian constitutional jurisprudence seems to sustain a parallel, competing, model of proportionality analysis. This other model views the 'primary, and perhaps only, role of proportionality [as being] to assess whether a law can be characterised as achieving the claimed legitimate purpose. ${ }^{172}$ This narrower vision of proportionality manifests principally in cases where the High Court is engaged in characterisation, rather than the application of constitutional guarantees or other limitations upon power. ${ }^{73}$ For convenience, this article will adopt the term 'robust proportionality' to describe a proportionality principle modelled on the European three-level approach. It will use the term 'abridged proportionality' to describe the narrower, alternative, conception in which proportionality analysis serves only to expose illegitimate legislative purposes. Importantly, the robust proportionality model directly and unashamedly requires judges to engage in evaluative reasoning, whereas the abridged proportionality model implicates such reasoning at best indirectly and minimally. ${ }^{74}$

These two approaches to judicial review - abridged proportionality and robust proportionality - need not be understood as close relatives. They might equally be viewed as entirely distinct, with each confined to a separate doctrinal sphere. Chief Justice Brennan took this view in Leask $v$ Commonwealth, describing 'proportionality' as a term that has acquired two distinct meanings in Australian constitutional

69 Ibid 8-9. This is true, at least, where proportionality analysis is employed in the context of constitutional guarantees. Where employed in the context of characterisation, that is, in testing a law's link to a head of legislative power, proportionality analysis may draw judges into evaluative reasoning at an earlier stage. Kirk contends that the application of level-two 'necessity' implicates value judgements in the characterisation setting where, as in Australia, judges are left with the task of identifying and articulating the relevant 'interests' to be protected from more than minimal interference: ibid 27.

70 While the European jurisprudence appears to treat the 'necessity' element as largely nonevaluative, this approach does not follow inevitably from the underlying concept. The necessity question could, and in some other settings does, take on greater evaluative significance. For instance, United States constitutional law employs, in the notion of 'less restrictive means', a concept similar to the 'necessity' element in European proportionality analysis. There, there seems to be greater scope and propensity for judicial value judgements to play a role in assessing issues of necessity.

71 Kirk, above n 44, 6, 9.

72 Ibid 24

73 Ibid 24, 27, 39-41.

74 But see discussion below at Section 4(ii) regarding the inevitability of some evaluative component, even if minimal only. 
jurisprudence. ${ }^{75}$ He saw the abridged kind of proportionality as operating in the context of characterisation and as being conceptually far removed from the robust kind of proportionality employed in the context of some constitutional guarantees. Other judges and commentators have gone further, disavowing the term 'proportionality' altogether in settings where the judicial task is essentially one of assessing legislative purpose. ${ }^{76}$

Kirk's account, on the other hand, attempts to reconcile the abridged and robust versions of proportionality analysis by portraying them as coherent variations upon a single core test. The operative variable is said to be the degree of judicial deference accorded to legislative bodies. Where deference is strong, judicial willingness to embark upon evaluative analysis will be greatly diminished and so proportionality analysis will take the abridged form. Where, on the other hand, deference is weaker and there is less reticence about evaluative assessments, emboldened judges will deploy robust proportionality analysis. Kirk contends that in the constitutional guarantee setting the High Court has embraced robust proportionality analysis, even while failing to articulate the three levels clearly. In contrast, he sees an abridged version of proportionality analysis as dominant in the characterisation context. ${ }^{77}$

In its treatment of the new section 92 jurisprudence, Kirk's proportionality account is both descriptive and prescriptive. Descriptively, he presents the section 92 jurisprudence as evidence that the High Court employs robust proportionality analysis in the constitutional guarantee setting. He contends that this approach predates section 92's overhaul in Cole $v$ Whitfield and is evident in the case law despite the Court's failure explicitly to articulate the three sequential and cumulative levels of analysis. ${ }^{78}$ The prescriptive part of the account contends that robust proportionality is, with limited exceptions, entirely appropriate in the section 92 context. ${ }^{79}$

The robust proportionality account of section 92 accepts that a finding of discriminatory protectionist purpose will be a sufficient condition for invalidity. But the account does not regard such a finding as a necessary condition for invalidity some laws will transgress section 92 even in the absence of improper purpose. In particular, a robust proportionality account presumes that the High Court sees unintended protectionist discrimination as potentially invalid under section 92 .

In suggesting that the Court has endorsed something resembling robust proportionality analysis in the section 92 context, ${ }^{80}$ Kirk's account places most

75 (1996) 187 CLR 579, 593-4 ('Leask').

76 See, eg, Nationwide News Pty Ltd $v$ Wills (1992) 177 CLR 1, 88-89 (Dawson J); Cunliffe $v$ Commonwealth (1994) 182 CLR 272, 377 (Toohey J) ('Cunliffe').

77 Kirk, above n 44, 41-2. Interestingly, United States constitutional scholar Vicki Jackson has applied Kirk's distinction - between the deference due in proportionality analysis in the characterisation context as compared with the 'constitutional guarantee' context - in an analysis of United States constitutional jurisprudence: Vicki Jackson, 'Ambivalent Resistance and Comparative Constitutionalism: Opening up the Conversation on 'Proportionality', Rights and Federalism' (1999) 1 University of Pennsylvania Journal of Constitutional Law 583, 605, 631-2.

78 Kirk, above n $44,12,14$.

79 Ibid 19-20, 59-60. Kirk acknowledges that complex and technical subject matter may warrant particular deference. In Section 4(vi) I discuss problems of judicial expertise and fact finding capability.

80 Ibid 14, 15-16. 
emphasis upon the reasoning in Castlemaine. ${ }^{81}$ The account acknowledges that an attribution of protectionist purpose at the 'suitability' level of robust proportionality analysis would halt the inquiry there, there being then no legitimate end to be scrutinised for necessity and balance at the second and third levels of analysis. ${ }^{82}$ Indeed, as '[t]he application of proportionality is premised on the legislative aim being a legitimate one', ${ }^{3}$ no law proceeding from the illegitimate purpose of protectionism could ever be rationalised by reference to its positive effects.

In Kirk's view the Castlemaine test 'implicitly acknowledges that the burden of the restriction on interstate trade has to be balanced against the benefit of achieving [a] legitimate end. ${ }^{184}$ He notes, however, that the leading judgment did not employ all three levels of proportionality analysis in reasoning to a conclusion on the specific facts of Castlemaine. ${ }^{85}$ Kirk's wider account notes that the Court does in some contexts limit itself in a way consistent with abridged proportionality analysis. ${ }^{86} \mathrm{He}$ does not, though, explore the possibility that the Court's use of proportionality analysis in the section 92 context proceeds upon the abridged rather than the robust version. This is not surprising, given the account's in-principle endorsement of robust proportionality analysis in the section 92 context. In Section 4 I will consider the appeal of this prescriptive stance more closely. For now, though, I will concentrate on assessing the plausibility of robust proportionality analysis as a descriptive account of the modern section 92 jurisprudence.

That the Court takes a robust proportionality approach to section 92 is, in my view, far from self-evident. Problems encountered by a robust proportionality account include the High Court's rejection of tiered analysis, the absence from the case law of any clearly evaluative reasoning, and the existence of several bases for inferring a principal interest in legislative purpose. The remainder of this Section considers these aspects of the cases.

It was earlier noted that a robust proportionality account of section 92 of necessity accords preliminary, and pivotal, significance to a determination of legislative purpose. ${ }^{87}$ Specifically, where a protectionist purpose is evident, it will be presumed that there is no 'legitimate end' warranting progression to the second and, more importantly, the third levels of proportionality analysis. ${ }^{88}$ However, in conceding necessarily that an inquiry into purpose and a balancing of effects stand in sequential relation to one another - that is, the latter only takes place when a law passes the former threshold test - a robust proportionality account of section 92 doctrine sits uncomfortably with the insistence in Castlemaine upon a single-stage, non-sequential,

(1990) 169 CLR 436, 473, cited by Kirk, above n 44, 14.

Kirk, above n 44, 15.

Ibid 5-6.

Ibid 15.

Ibid 14.

Ibid 24-5, 41.

Ibid 6, emphasising the attention given to purpose in the reasoning in Castlemaine.

Ibid 15. In other words, even if a legislative provision evidenced additional, benign, purposes, whether intended or not, a protectionist purpose would infect it beyond redemption. It is always possible that a court would hesitate in a case where the protectionist purpose seemed minor or secondary. The High Court has given little attention to this question of degree in its reasons. It is not, in any case, important to my analysis. 
inquiry. ${ }^{89}$ Even while the leading judgment in Castlemaine may misdescribe key aspects of the United States dormant commerce clause jurisprudence, its insistence upon 'one inquiry' seems among other things to require that considerations of purpose and effect come into play together, rather than sequentially.

Also problematic for a robust proportionality account of existing section 92 jurisprudence is the apparent absence of evaluative reasoning in Castlemaine. No thirdlevel balancing was undertaken. Rather, the leading judgment's conclusions were grounded in the perceived lack of fit between an asserted benign purpose and the law's actual operation, which 'suggested the scheme was not really adopted for the purpose claimed. ${ }^{.90}$ Kirk considers that second level 'necessity' considerations underpinned one part of the leading judgment's reasoning - the assertion that the State's energy conservation goals could have been pursued in ways less damaging to interstate trade. ${ }^{91}$ However, as mentioned earlier, the necessity stage of European-style proportionality analysis is not inherently evaluative. Moreover, nothing indicates that the leading judgment's observation amounted, on this occasion, to anything more than a further basis for inferring improper purpose. ${ }^{92}$ Indeed, Kirk's wider analysis cites Castlemaine as the chief example of how assessments of necessity can serve that purely evidentiary role. ${ }^{93}$

Several further features of Castlemaine zero in upon legislative purpose in a way that undermines the robust proportionality account. First, the leading judgment, in mining the United States Supreme Court's jurisprudence for helpful pointers, appeared interested only in extracting techniques for inferring legislative purpose. It is worth quoting the crucial passage at length:

Although the American cases cannot be treated as an accurate guide to the interpretation of s 92, they identify in a useful way considerations which may be relevant in the process of characterization which an Australian court is called upon to undertake. ... [T]he fact that a law, whose effects include the burdening of the trade of a particular interstate trader, does not necessarily benefit local traders, as distinct from other interstate traders, suggests that the purposes of the law are not protectionist. On the other hand, where a law on its face is apt to secure a legitimate object but its effect is to impose a discriminatory burden upon interstate trade as against intrastate trade, the existence of reasonable non-discriminatory alternative means of securing that legitimate object suggests that the purpose of the law is not to achieve that legitimate object but rather to effect a form of prohibited discrimination. There is also some room for a comparison, if not a balancing, of means and objects in the context of s 92. The fact that a law imposes a burden upon interstate trade and commerce that is not incidental or that is disproportionate to the attainment of the legitimate object of the law may show that the true purpose of the law is not to attain that object but to impose the impermissible burden. 94

The fact that the leading judgment described its task as one of 'characterization' and was careful to invoke the term 'balancing' in a limited means-ends sense only suggests

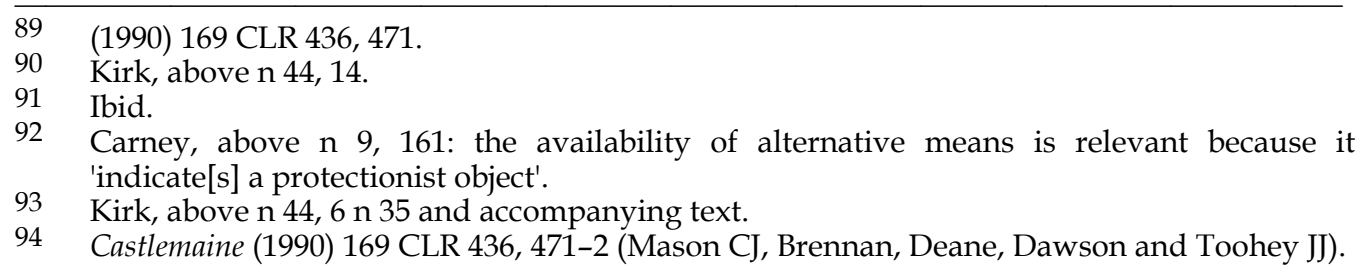


a conscious stopping short of the evaluative analysis that distinguishes the robust model of proportionality.

Also suggestive of an emphasis upon purpose is the leading judgment's parallel in Castlemaine to the 'analogous field' of section 51(xxix) external affairs jurisprudence. While that jurisprudence concerns the characterisation of laws by reference to a subject matter, it is a subject matter understood to have a significant 'purposive aspect' where concerned with implementing treaty provisions. ${ }^{95}$ Some members of the High Court have at times seemingly engaged in robust proportionality analysis while undertaking characterisation having a purposive element. ${ }^{96}$ Nevertheless, while the dominant position may have seemed uncertain in 1990 when Castlemaine was decided, a majority of the Court has since indicated that robust proportionality was never an accepted approach in the characterisation context. ${ }^{97}$ In the vanguard of this disavowal were three of the five judges who had joined in the leading judgment in Castlemaine. ${ }^{98}$ This suggests that the Court in Castlemaine, in analogising its section 92 approach to the task of characterisation under section 51(xxix), was invoking, at most, the abridged version of proportionality analysis. ${ }^{99}$

Finally, an indirect indication that Castlemaine endorses a principal focus upon purpose can be found in the separate judgment of Gaudron and McHugh JJ. Those separate reasons sought to isolate the 'discrimination' component of section 92, so as to align it with a wider conception of discrimination extending beyond the immediate setting. Subsequent commentary on the decision has suggested alternative, or additional, explanations lying behind the separate reasons. ${ }^{100}$ One thing that appears to distinguish Gaudron and McHugh JJ's judgment is its position on unintentional protectionist discrimination. They rejected the leading judgment's test as incomplete, in that it would not necessarily catch all laws for which the 'practical effect is protectionist'. ${ }^{101}$ Justices Gaudron and McHugh evidently thought section 92 ought to catch all such laws. ${ }^{102}$ In other words, section 92 must be presumed to extend beyond intentional burdens and also to target burdens that are inadvertent yet unjustified.

In terms of the competing models of proportionality, this perspective on Gaudron and McHugh JJ's separate reasons is telling. Abridged proportionality analysis, confined in essence to the objective assessment of purpose, cannot accommodate a wider focus on unintentional protectionist discrimination. Rather, a conception of section 92 as extending to unintended effects would, if engaging any conception of proportionality, require the robust version. That Gaudron and McHugh JJ distinguished their analysis by asserting section 92's necessary concern with

95 Cunliffe (1994) 182 CLR 272, 322 (Brennan J); Victoria v Commonwealth (Industrial Relations Act Case) (1996) 187 CLR 416, 487 (Brennan CJ, Toohey, Gaudron, McHugh and Gummow JJ). Generally, the High Court's constitutional jurisprudence distinguishes between heads of law-making power conferred by reference to some purpose ('purposive' powers) and those conferred by reference to a nominated subject matter ('subject matter' powers).

96 Kirk, above n 44, 31-4.

97 See the cases cited by Kirk, ibid 38-40.

98 Nationwide News Pty Ltd v Wills (1992) 177 CLR 1, 88-9 (Dawson J); Cunliffe (1994) 182 CLR 272, 377 (Toohey J); Leask (1996) 187 CLR 579, 593-5 (Brennan CJ).

99 (1990) 169 CLR 436, 473.

100 Zines, above n 1, 143; Rose, above n 1, 342.

101 (1990) 169 CLR 436, 480.

102 Ibid. 
unintended effects indicates that the leading judgment's proposed test, as Gaudron and McHugh JJ understood it, is concerned only with inferring legislative purpose. This in turn suggests that the leading judgment, if it endorses any kind of proportionality analysis, must be taken to endorse only the abridged kind.

Taken together, these considerations indicate that, at a descriptive level, the robust proportionality account lacks a firm footing in existing section 92 case law. While a High Court majority has recently approached at least one other constitutional nondiscrimination norm in a way apparently sympathetic to the robust proportionality approach, this does not resolve the uncertainty attending section 92. ${ }^{103}$ Rather, as I mentioned earlier, the Court's recent decision in APLA seems to leave the matter hanging quite palpably. This will only serve to create confusion in other courts, where appellate decisions have already begun to reach opposing conclusions about the nature of the section 92 test. ${ }^{104}$ In Section 4 I suggest a way forward by recourse to prescriptive analysis.

\section{THE CASE FOR A PURPOSE-FOCUSED DOCTRINE}

Sections 2 and 3 canvassed two descriptive theories as to the precise doctrinal contours of the modern section 92 jurisprudence - the purpose-focused theory and the robust proportionality theory. I have claimed that neither finds conclusive support in the contemporary case law. Rather, the often vague and internally contradictory reasoning suggests that members of the Court were perhaps unable to agree upon section 92's detailed contours and outer limits. Accordingly, there is worth in an evaluation of the options. In this Section I revisit from a prescriptive standpoint the competing positions described in Sections 2 and 3, concluding that the Court ought to adopt a purposefocused conception of the section 92 norm and reframe its test accordingly. ${ }^{105}$

I will argue from the High Court's premise of a 'national unity' rationale that section 92 is best understood as a provision of federal structural significance, rather than as a provision intended primarily to secure the economic wellbeing of citizens. For this reason, I contend, the most appropriate conception of the section 92 test is one accepting improper legislative purpose as a necessary, rather than a merely sufficient, element in triggering the provision - ultimately, an approach excluding unintentional protectionist discrimination from section 92's purview. Aside from its philosophical appeal, that approach has the added practical benefit of responding to standard criticisms raised in the section 92 context regarding the Court's fact-finding capacity and its competence in economic analysis.

103 See Permanent Trustee Australia Ltd v Commissioner of State Revenue (2004) 211 ALR 18, interpreting the s 99 prohibition on the Commonwealth's 'giv[ing] preference' in matters of trade, commerce and revenue.

104 Compare the Full Federal Court's decision in Sportodds Systems Pty Ltd $v$ New South Wales (2003) 133 FCR 63, 76-7 ('Sportodds') with Cross v Barnes Towing and Salvage (Qld) Pty Ltd [2005] NSWCA 273 (Unreported, Spigelman CJ, Handley and Beazley JJA, 8 August 2005) [53], [68], [108].

105 A similar claim is made by Rose, above n 1, 346, although there it is only one among several prescriptions and so the argument in support is limited to a few lines. 


\section{(i) National unity as a rationale}

It is often presumed, in Australia as elsewhere, that objections to protectionism are grounded directly in economic concerns. In other words, it is assumed that 'free trade' - in the sense of an uninhibited flow of articles of commerce over borders - is valued for its supposed contribution to the economic wellbeing of citizens. The emergence of institutions of global and regional governance, including the World Trade Organization, premised on the economic value of free trade has doubtless fuelled an implicit assumption that anti-protectionist rules in national legal systems share that same normative foundation. There are, however, other potential rationales that might underpin an objection to protectionism.

One such alternative, given some attention in the scholarship on the United States Constitution's 'dormant commerce clause', styles anti-protectionist legal norms as a form of structural safeguard offering principally political benefits. ${ }^{106}$ From this perspective anti-protectionist legal norms are seen as geared to discouraging certain behaviour on the part of component units of a federal polity, for reasons concerned more with the preservation of that polity than with the economics of free trade. I will argue in this Section that the High Court, in asserting section 92's rationale to be the furthering of national unity, has committed itself to this kind of federal structural understanding of section 92. Consequently, a purpose-focused test should be the principal touchstone by which determinations of protectionist discrimination are made.

As explained earlier, the Court in Cole $v$ Whitfield gave detailed and careful consideration to section 92's drafting history as a means of making some sense of the provision's sparse text. The Court was clear in its view that section 92 was intended to preclude 'the imposition of protectionist burdens' ${ }^{107}$ However, the discussion in Cole does not clarify precisely why it was thought desirable to deny that power to the component governments of the federation. The passages that the Court extracts from the Convention Debates suggest several possible rationales. As will emerge, isolating a rationale for the section 92 norm assists, in turn, in identifying the preferable touchstone for the norm's application. First, though, the various possibilities must be canvassed.

In his analysis of the US dormant commerce clause jurisprudence, Donald Regan nominates three distinct rationales that might underlie an anti-protectionist norm in a federal constitution. These rationales are concerned, respectively, with the 'concept of union', 'resentment/retaliation', and 'efficiency'. ${ }^{108}$ The 'concept of union' rationale proceeds from the view that '[s]tate protectionism is unacceptable because it is inconsistent with the very idea of political union, even a limited federal union. Protectionist legislation is the economic equivalent of war. It is hostile in its essence. ${ }^{109}$ While Regan views 'resentment/retaliation' as a free-standing rationale for an antiprotectionist norm, it is arguably just one aspect of the 'concept of union' rationale - a practical shade to the broader philosophical concern. The 'resentment/retaliation' rationale, in essence, understands protectionism as a collective action problem. It

106 See, in particular, Donald Regan, 'The Supreme Court and State Protectionism: Making Sense of the Dormant Commerce Clause' (1986) 84 Michigan Law Review 1091.

107 (1988) 165 CLR 360, 393.

108 Regan, above n 106, 1112-16.

109 Ibid 1113. 
contends that '[i]f protectionist legislation is permitted at all, it is likely to generate a cycle of escalating animosity and isolation.' ${ }^{110}$ Again, though, the ultimate concern is with the preservation of the federation, a cycle of animosity being a likely source of destabilisation. An anti-protectionist norm growing out of this kind of concern represents, then, a prophylactic measure against a dangerous political pathology. In the constitutional context it represents a pre-commitment to the long-range benefits of federal union.

While Regan's first two suggested rationales may be shades of a single concern, his third, the 'efficiency' rationale, is truly distinct. When invoked as an explanation for an anti-protectionist norm, 'efficiency' essentially replicates the abstract economic principle, though with a nod to political considerations. As Regan frames the rationale, 'protectionism is inefficient because it diverts business away from presumptively lowcost producers without any ... federally cognizable benefit.' 111 In other words, efficiency is understood as a 'good' according to the standard economic explanation, yet one that can be traded off against other goods in the political arena.

Importantly, this 'efficiency' rationale for an anti-protectionist norm differs from the others discussed by Regan in that it is premised on free trade's economic value. It assumes that prohibiting protectionism is something done to further the economic wellbeing of citizens. In contrast, explanations grounded in a concern for the viability of federal union value anti-protectionist norms predominantly, if not entirely, for political reasons. Where the ultimate end served by an anti-protectionist norm is the preservation of the federal polity, the norm takes on federal structural significance.

The distinction between economic and political rationales for adopting an antiprotectionist norm does not feature in the High Court's examination of section 92's drafting history in Cole $v$ Whitfield. While concluding that section 92 was intended as an anti-protectionist norm, the Court does not attempt to go further and distil an underlying rationale. Subsequent cases suggest, however, that the Court accepts some version of the federal structural rationale as preferable to, or at least predominant over, any explanation grounded in the economic value of free trade. In Castlemaine, the leading judgment found value in the United States dormant commerce clause jurisprudence only in so far as it focused upon the goal of preserving a 'national economic unit'. To the extent that that jurisprudence is concerned with 'broader notions of free trade' it was deemed unhelpful. ${ }^{112}$ That position was again evident in Barley Marketing Board, the unanimous Court finding:

The United States decisions provide limited assistance. That is because some of them proceed according to the view that the object of the commerce clause was to bring into existence a free market economy or a free trade area in the sense that restrictions on competition are unconstitutional. That interpretation of the commerce clause gives it a more wide-ranging operation than Cole $v$ Whitfield accords to $s 92 \ldots 113$

110 Ibid 1114

111 Ibid 1118.

112 Castlemaine (1990) 169 CLR 436, 470.

113 (1990) 171 CLR 182, 203-4. 
Indeed, the very text of section 92, in fixing upon interstate trade rather than concerning itself with trade generally, prevents its being cast as a true free trade provision. ${ }^{114}$

That the Court sees section 92 as ascribing federal structural, rather than principally economic, value to an absence of protectionism is likewise suggested by its treatment of the related non-discrimination norm found in section 117 of the Constitution. Section 117 provides:

A subject of the Queen, resident in any State, shall not be subject in any other State to any

disability or discrimination which would not be equally applicable to him if he were a

subject of the Queen resident in such other State.

The Court has emphasised repeatedly that sections 92 and 117 are closely related constitutional provisions. In the leading case discussing the nature and scope of section 117, Street $v$ Queensland Bar Association, 115 the judgments disclose a general acceptance that that provision is grounded in a national unity rationale. Importantly, several members of the Court observed that section 92 shares the same rationale. Chief Justice Mason explained sections 92 and 117 as provisions 'designed to enhance national unity', 116 while Brennan J considered that '[s]ections 92 and 117 are the constitutional pillars of the legal and social unity of the Australian people'. ${ }^{117}$ Justice Deane emphasised that both sections 92 and 117 represent 'structural provision[s] directed to the promotion of national economic and social cohesion'118 and Gaudron J seemed also to attribute a 'federal purpose' to both provisions. ${ }^{119}$

Apparently, then, the High Court understands section 92 as a provision directed at least principally to fostering and preserving national unity through the control of powerful forces that might otherwise cause the federal pact to unravel. ${ }^{120}$ However, a further puzzle remains. The dangers against which section 92 takes precaution could be understood to be protectionist effects, or protectionist legislative purposes, or both. The conclusion that section 92's rationale stems from federal structural considerations ought to guide the Court to an answer.

(ii) Legislative purpose tests - objective or subjective?

In contemplating legislative purpose as a potential touchstone of validity, I have so far evaded the question of precisely how that purpose is best conceptualised and ascertained. The question warrants a digression, though, as the range of possible conceptions of legislative intention or purpose, and the coherence, desirability, and

114 An earlier draft of section 92 concerned itself with freedom of trade 'within the Commonwealth'. This was intentionally changed to 'between the States', and ultimately to 'among the States': Official Record of the Debates of the Australasian Federal Convention, Melbourne, 16 February 1898, 1014-20; Official Record of the Debates of the Australasian Federal Convention, Melbourne, 11 March 1898, 2365 (Sir Isaac Isaacs).

115 (1989) 168 CLR 461.

116 Ibid 485.

117 Ibid 512

118 Ibid 522

119 Ibid 570.

120 While this may not have been the sole rationale for the inclusion of section 92 in the Constitution - a more general desire to promote economic wellbeing probably motivated some supporters of the provision - the Convention Debates suggest, and the High Court has accepted, that it was the predominant rationale. 
practicality of different models, is an issue that has long troubled judges and scholars. ${ }^{121}$

A preliminary complication concerns the appropriate terminology. Discussions of the different variants of purpose-based tests often employ key terms imprecisely and inconsistently. Judges and scholars have talked variously in terms of legislative 'intention', 'motive', and 'purpose'. Some discussions seem to treat those terms as interchangeable, while others distinguish them explicitly. When they are distinguished, it is typically on the basis that 'intention' or 'motive' refers to the actual mental states of legislative actors, whereas 'purpose' is an objectively determined attribute turning upon projected impressions. ${ }^{122}$ Complexities and complications abound, however. For example, various shades can be separated out within each of the core classifications just described, and the essential inquiry could be undertaken at numerous levels of generality. ${ }^{123}$ The concepts may also compound - legislators may have subjective intentions about the objective purpose that a law will project, perhaps fuelled by a submerged motive. Rather than become distracted by the possibilities, I will focus attention upon the core distinction that matters most for my analysis, being a distinction between the subjective motives or intentions of legislators and the objective purpose of legislation.

In constitutional review, as in statutory construction, judges have long distinguished between the idea of legislators' subjective motives, on the one hand, and the objective purpose of a statute's provisions, on the other. ${ }^{124}$ Despite that in-principle distinction, there is necessary overlap in the approaches to evidence gathering underpinning each kind of inquiry. Inquiry into subjective legislator motive or intention seeks to identify the actual mental states of legislators, 125 that is, what they hope or intend to achieve by enacting the provisions in question. However, as in other fields of law where actual mental states are pivotal, the subjective motives or intentions of legislators typically must be inferred from surrounding facts and circumstances, including the law's operation and effect. ${ }^{126}$ It is in this sense that subjective motive or intention inquiry often resembles, and may be mistaken for, objective purpose inquiry. The latter is, of course, heavily reliant upon evidence as to a law's operation and effect. Crucially, though, it attaches direct, rather than inferential, significance to those

121 Many of the important questions receive treatment in Kent Greenawalt, Statutory Interpretation: 20 Questions (1999); Kent Greenawalt, 'Are Mental States Relevant for Statutory and Constitutional Interpretation?' (2000) 85 Cornell Law Review 1609.

122 See Stenhouse v Coleman (1944) 69 CLR 457, 471 (Dixon J); Richardson v Forestry Commission (1988) 164 CLR 261, 311 (Deane J).

123 For instance, 'intentions' are susceptible of various gradations of specificity and directness, while the 'readers' from whose standpoint objective legislative purpose is inferred could be modelled in numerous ways. A careful, comprehensive, account of these and other variables is provided by Greenawalt, Statutory Interpretation, above $\mathrm{n} 121$, chs V and IX. On levels of generality, see Aharon Barak, 'Foreword: A Judge on Judging: The Role of a Supreme Court in a Democracy' (2002) 116 Harvard Law Review 16, 75-6.

124 In Australia, the leading authority is Stenhouse v Coleman (1944) 69 CLR 457. In the United States, the distinction has been put most forcefully in recent times by Justice Scalia. See, eg, Edwards v Aguillard, 482 US 578, 636-9 (1987) (Scalia J, dissenting).

125 Precisely whose subjective intentions count - as between all legislators, only some legislators, or perhaps influential non-legislators - represents another point of contention in the scholarship. See Greenawalt, Statutory Interpretation, above n 121, ch X. Ibid ch XI; Barak, above n 123, 74; Kirk, above n 44, 6 . 
considerations. This is because a determination of objective purpose represents a conclusion about what a statute seems, from a reader's perspective, to have as its purpose.

While both kinds of inquiry - subjective motive inquiry and objective purpose inquiry - have attracted judicial and scholarly criticism, the subjective version has borne the greater share. The critique of subjective motive or intention tests has both empirical and normative dimensions, as those tests have been challenged as to their practicality and coherence as well as their legitimacy and value. In its empirical dimension the critique has been taken furthest in the United States, most notably by influential judicial champions including Supreme Court Justice Antonin Scalia. ${ }^{127}$ A good deal of the concern about subjective motive or intention inquiry in the United States has centred upon the supposed difficulty of attributing coherent and determinate 'motives' or 'intentions' to collective bodies. ${ }^{128}$ Objections of that nature likely hold less force in an Australian parliamentary context, where a system of cabinet government together with strong party discipline makes distillation of relevant legislative intentions and motives a more realistic undertaking. ${ }^{129}$

These institutional features do not, though, provide an answer to the normative dimension of the critique of subjective purpose inquiry. It is this dimension that seems to drive the High Court's expressed concerns. To the extent that the Court inquires into such things, it has always been careful to distinguish between subjective and objective conceptions of purpose and to direct its inquiry to the latter. ${ }^{130}$ The classic statement of the Court's position is that of Dixon J in Stenhouse v Coleman. ${ }^{131}$ In explaining the sense in which 'purpose' is relevant to the characterisation of laws made under purposive heads of power, Dixon J reaffirmed 'the practice that excludes from investigation the actual extrinsic motives and intentions of legislative authorities. ${ }^{132}$ Rather, he said, the relevant purpose is an imputed one, to be 'collected from the instrument in question, the facts to which it applies and the circumstances which called it forth. ${ }^{133}$ Those views have been endorsed repeatedly by members of the Court in the context of

127 Edwards $v$ Aguillard, 482 US 578, 636-9 (1987) (Scalia J, dissenting). Justice Scalia has elsewhere echoed the normative critique: Antonin Scalia, A Matter of Interpretation: Federal Courts and the Law (1997) 17.

128 See, eg, Frank Easterbrook, 'Statutes' Domains' (1983) 50 University of Chicago Law Review 533, 547; Jeremy Waldron, 'Legislators' Intentions and Unintentional Legislation' in Andrei Marmor (ed), Law and Interpretation (1995) 329.

129 Kent Greenawalt has noted, along similar lines, the likely diminution of the empirical critique when applied to Cabinet government systems: Greenawalt, Statutory Interpretation, above $\mathrm{n} 121,111-12$. Members of the High Court have long acknowledged the empirical critique, though in the context of deliberative bodies other than parliaments: Arthur Yates $\mathcal{E}$ Co Ltd $v$ The Vegetable Seeds Committee (1945) 72 CLR 37.

130 The Court is, of course, more relaxed about subjective purpose inquiry where such inquiry is directed $b y$, rather than at, a legislature, in the form of a statutorily mandated test. See, eg, News Limited $v$ South Sydney District Rugby League Football Club Limited (2003) 215 CLR 563.

131 (1944) 69 CLR 457.

132 Ibid 471. Presumably, Dixon J would exclude here all variants on subjective purpose inquiry, such as consideration of legislators' subjective purposes in enacting a statute, as well as their intentions as to the purpose that would be attributed to a particular statute. Ibid. 
purposive characterisation, ${ }^{134}$ and similar sentiments have been expressed in other interpretative contexts. ${ }^{135}$

Historically, in constitutional systems springing from and modelled upon the British system, the reluctance to inquire into legislators' subjective motives or intentions has reflected the deference demanded by the doctrine of parliamentary supremacy. Doubtless this has influenced the High Court's position. ${ }^{136}$ Nevertheless, the Court has at times hinted at a further normative reason for retaining a degree of objectivity in purpose inquiry, at least in the characterisation context. This further reason springs from the other side of the Janus-faced model of Australian constitutionalism - the Madisonian tradition of confining legislative power and subjecting it to judicial review. ${ }^{137}$ That other potential rationale is this: maintaining some objective element within an inquiry into legislative purpose ensures that legislative power remains effectively constrained.

That subjective intention or motive inquiry is especially problematic in the characterisation context seems to be reflected in scholarly treatments of such inquiry. To the extent that subjective inquiry has won in-principle endorsement from scholars and judges this has typically come, at least implicitly, in the context of general statutory interpretation where the issue facing a court is what statutory language means. ${ }^{138}$ Arguably, legislators' asserted intentions and purposes will be more trustworthy on those occasions than in cases where the issue is instead a statute's validity. To defer completely to legislators' assertions regarding the purpose of a

134 See, eg, Australian Communist Party v Commonwealth (1951) 83 CLR 1, 254 (Fullagar J), 274 (Kitto J). For a more recent statement, see Richardson v Forestry Commission (1988) 164 CLR 261, 311 (Deane J): 'The reference to such a purpose or object is not, of course, to the subjective motives or purposes of the various members of the Parliament which enacted the law. It is a reference to the purpose or object of the law itself - that which it can be seen to be designed to serve or achieve.'

135 For example, in Cole $v$ Whitfield (1988) 165 CLR 360, 385, the Court set out its position on the use of drafting history in the interpretation of provisions of the Constitution:

Reference to the history of [constitutional provisions] may be made, not for the purpose of substituting for the meaning of the words used the scope and effect - if such could be established - which the founding fathers subjectively intended the section to have, but for the purpose of identifying the contemporary meaning of language used, the subject to which that language was directed and the nature and objectives of the movement towards federation from which the compact of the Constitution finally emerged.

In other words, the Court advocated an objective, 'reader understanding', inquiry rather than an inquiry into the actual, subjective, mental states of the framers.

136 For an early indication, see $R v$ Barger (1908) 6 CLR 41, 75 (Griffith CJ, Barton and O'Connor JJ). For discussion in the specific context of s 92, see Sawer, above n 10, 178, 190.

137 Plaintiff S157 v Commonwealth (2003) 211 CLR 476, 513-4 (Gaudron, McHugh, Gummow, Kirby and Hayne JJ); Australian Communist Party v Commonwealth (1951) 83 CLR 1, 262 (Fullagar J); Commonwealth v Mewett (1997) 191 CLR 471, 497 (Dawson J), 547 (Gummow and Kirby JJ). See generally Harry Evans, 'Hobbes versus Madison and Isaacs versus Baker: Contrary Theories and Practices in Australian Democracy' (2001) 24 University of New South Wales Law Journal 701.

138 Greenawalt, for example, maintains a principal focus upon the statutory interpretation context, while asserting that the context of constitutional interpretation would be broadly analogous: Greenawalt, 'Are Mental States Relevant', above n 121, 1672. 
statute, where testing its validity against a purposive head of legislative power, would effectively undermine judicial review. As the High Court explained in Australian Communist Party $v$ Commonwealth, a legislature with limited power ought not to be permitted to define the scope of that power. ${ }^{139}$

While judges might, in some contexts, perceive their own interpretative methodology to involve inquiry into legislators' subjective mental states, this seems an oversimplification in the characterisation context. In order for judicial review to have meaning there, a court must retain some scope for second-guessing asserted legislative purposes. ${ }^{140}$ Second-guessing of this kind necessarily introduces an objective component into the inquiry, as it involves a court seeking confirmation of a legislature's claimed purpose by reference to a law's apparent purpose. With this in mind, the distinction between so-called 'subjective' and 'objective' inquiry into a law's purpose appears as one of degree rather than principle. In endorsing either, courts are really only selecting the degree of deference that they extend to legislators - that is, indicating just how much disjunction they will tolerate as between the purpose asserted for a law and the purpose which its terms and operation suggest. ${ }^{141}$

Importantly, to concede some role, however small, to objectivity in the assessment of legislative purpose is also to concede some role to evaluative balancing. To conclude that a legislature's asserted purpose cannot be its 'real' purpose is necessarily to pass judgement upon - that is, to evaluate - the rationality and desirability of the former. To illustrate, imagine that the High Court's decision in Castlemaine did in fact turn upon legislative purpose - that is, that the State's laws were found invalid because their 'real' purpose was protectionist discrimination. This conclusion about real purpose could not be reached unless the Court found the asserted environmental and litter control purposes implausible. A judgement of implausibility involves, in turn, an assessment that particular benefits, secured in a given magnitude, would be marginal, trivial, or otherwise unworthy of legislative attention. ${ }^{142}$ This is inescapably a normative judgement.

139 See, eg, (1951) 83 CLR 1,274 (Kitto J). See also Richardson v Forestry Commission (1988) 164 CLR 261, 307 (Deane J).

140 See Michael Dorf, 'A Partial Defense of an Anti-Discrimination Principle', Issues in Legal Scholarship: The Origins and Fate of Antisubordination Theory (2002) Article 2, 12 <http://www.bepress.com/ils/iss2/art2> at 20 October 2005: 'Ends analysis is needed to sort sham from real purposes, because of the possibility of articulating some purpose to which any policy is narrowly tailored.' See also Charles Fried, 'Types' (1997) 14 Constitutional Commentary 55, 61-2.

141 The assertion of legislators' subjective intent about a statute will often just be implicit in the fact of its enactment. In enacting a law, legislators are generally implying that they believe it to be a valid exercise of legitimate power. Usually, but not always, the context will reveal the precise power or powers upon which that implicit reliance is based.

142 This kind of assessment finds expression in the majority judgment in Castlemaine, which acknowledges State legislative power to make laws addressing a 'real danger', presumably as distinct from an imagined danger or illusory danger: (1990) 169 CLR 436, 472. 
Under normal circumstances, ${ }^{143}$ then, what sets a so-called subjective legislative intention or purpose inquiry apart from an objective inquiry is a greater judicial willingness to defer to a legislature's asserted purposes - in the terminology of European proportionality jurisprudence, a greater 'margin of appreciation'. ${ }^{144}$ Accordingly, any proposal for a purpose-focused test must accept as inescapable some element of evaluation and objectivity within the judicial inquiry. Necessarily, such tests posit minimal evaluative reasoning rather than a complete absence of it. ${ }^{145}$

Having confirmed that purpose-focused tests of validity are viable in principle, I will now return to the section 92 context and consider whether such a test represents a suitable anchor for the modern section 92 jurisprudence.

\section{(iii) Federal structural concerns point to a purpose-focused test}

Where an absence of protectionism is valued principally for its contribution to the economic wellbeing of citizens, it stands to reason that an anti-protectionism norm would concern itself, ideally, with the actual effects of impugned laws rather than just the purpose for which they were made. ${ }^{146}$ When viewed from this perspective it is, principally, the actuality of harm that is objectionable, and the damage thus done is not lessened by the revelation that it was inadvertent. This is consistent with the orientation of economics as a discipline towards empiricism and pragmatism. On the other hand, anti-protectionism norms geared to the political aim of national unity in a federation may well be oriented differently. Where the erosion of federal goodwill is the concern, a law's purpose may take on greater significance.

To the extent that a law's effects are suggestive of federal ill-will they obviously will engage a national unity rationale. Yet it is an oversimplification to treat protectionist effects and a protectionist purpose as coextensive. A law's actual effects may sometimes include a burdening of interstate trade and an advantaging of intrastate trade without inviting an inference of protectionist purpose. This is typically true of,

143 I am assuming that, almost always, legislatures will be either silent as to the purpose of law, or will assert for it some non-protectionist purpose. It is nevertheless possible that, on occasion, a subjective purpose of protectionist discrimination will be articulated in circumstances where an objective purpose test might not have revealed it; see, eg, Sportodds (2003) 133 FCR 63, 78-9. In such cases, a preference for a subjective conception of purpose could not really be characterised as deferential to the legislature.

144 See Handyside v United Kingdom (1976) 24 Eur Court HR (ser A). More generally, see Louis Henkin et al, Human Rights (1999) 564-75; Michael Fordham and Thomas de la Mare, 'Identifying the Principles of Proportionality' in Jeffrey Jowell and Jonathan Cooper (eds), Understanding Human Rights Principles (2001) 27, 54. The term has been employed directly by some members of the High Court, most notably by Brennan CJ: Australian Capital Television Pty Ltd $v$ Commonwealth [No 2] (1992) 177 CLR 106, 159; Theophanous v Herald $\mathcal{E}$ Weekly Times Ltd (1994) 182 CLR 104, 156; Cunliffe (1994) 182 CLR 272, 325; Leask (1996) 187 CLR 579, 595.

145 Kirk also seems to suggest that, in characterising laws by reference to purposive powers, the Court cannot sensibly disavow evaluative reasoning altogether, but ought instead to settle for a very deferential mode of review: Kirk, above n 44, 42.

146 It may be that there is some separate reason, not concerned with the relevance of actual effects, for administering a norm by reference to some other criterion. For instance, concerns about judicial competence and legitimacy may lead to the adoption of a touchstone other than actual effects, notwithstanding that the latter seems more suitable in the abstract. 
for instance, a restriction on imports in response to a realistic prospect of disease or pest infestation. While interstate traders may be disgruntled at restrictions of that kind, the difficulty of inferring a protectionist legislative purpose makes such laws an unlikely trigger for cyclical reprisals threatening to unravel the federal compact. ${ }^{147}$

Everyday experience tells us that goodwill breaks down as a result of ill-intentions, more so than as a consequence of inadvertent yet harmful actions. ${ }^{148}$ In AngloAmerican legal systems, the general preference for a subjective mental element in the definition of criminal offences likewise attests to the centrality of intent to general notions of anti-sociability. ${ }^{149}$ Along similar lines, evidence of protectionist effect, to the extent that it engages the prohibition contained in section 92, is best understood as doing so because it evidences the male fides that section 92 proscribes. Truly unforeseen protectionist consequences may be easily remedied by a well-intentioned State once they come to light. An effects-based test operating as the interpretative equivalent of an absolute liability standard would do little to advance national unity. ${ }^{150}$

Essentially, then, my contention is that conclusions concerning legislative purpose are more important than those regarding a law's bare effects, in determining how protectionist discrimination impacts upon national unity. There is obviously a decent pinch of conjecture in the mix here. Nevertheless, I think it intuitive enough that burdens upon interstate trade that are presumptively intended - in that self-interested parochialism seems the most viable explanation - will do most to poison the goodwill sustaining federal union. Accordingly, where an anti-protectionism norm takes as its primary rationale a desire to preserve that union, its operation ought principally to turn upon some conception of legislative purpose or intention, rather than upon a law's bare effects.

If a purpose-focused touchstone for section 92 is indeed preferable, what form ought it to take? The considerations outlined in the previous sub-section suggest a ready answer. In that the High Court has always favoured objective purpose inquiry, and in that effective judicial review in any case demands some objective element, it seems appropriate in the section 92 context to understand purpose objectively. As it happens, this same conclusion was reached by both judges who examined the issue recently in APLA. ${ }^{151}$ The relevant inquiry should, then, generally be whether a law's objective purpose is protectionist discrimination, rather than whether such discrimination represented the subjective motive or intention of legislators. ${ }^{152}$

147 Regan, above n 106, 1133-4.

148 'Even a dog distinguishes between being stumbled over and being kicked': Oliver Wendell Holmes Jr, The Common Law (Mark DeWolfe Howe (ed) 1963, first published 1881) 7. See also Fried, above $n$ 140, 64.

149 This emphasis can be seen in the default position on culpability contained in federal model criminal codes in Australia and the United States: Criminal Code Act 1995 (Cth) sch $1 \mathrm{cl}$ 5.6; Model Criminal Code: American Law Institute, Model Penal Code and Commentaries, Part $1 \S 2.02(3)$ (1980).

150 An effects-focused standard of course need not be absolute. However, as the next subsection explains, there are in the section 92 context independent reasons for rejecting any effects-based test coupled to a proviso of 'reasonable regulation'.

151 (2005) 219 ALR 403, 449 [178] (Gummow J), 507 [423]-[424] (Hayne J).

152 In the unusual case where there is clear evidence of a discriminatory subjective intention then the test arguably should adopt a subjective standard directly, as this would best further s 92's rationale of preserving federal goodwill. Such evidence was apparently a 
Importantly, the objective test allows the Court to combat, relatively graciously, legislators' attempts to manipulate its inquiry by pressing dubious accounts of purpose upon it. ${ }^{153}$ For this reason, an objective purpose test may also be the best means of uncovering subjective motives and intentions.

A separate question is the degree of deference that should accompany application of a purpose-focused test. While that question implicates the complex and contested notion of judicial legitimacy, discussion of which would warrant a separate article, it is worth noting nevertheless that deference may already have proved a significant consideration in shaping the High Court's modern section 92 jurisprudence. Specifically, it may be that a reluctance to be seen to be questioning legislative goodwill actually led the Court to understate the significance of purpose in the application of section $92 .{ }^{154}$

The Court's general sensitivity about overstepping its perceived institutional bounds surfaced in Castlemaine, the leading judgment expressing the concern as follows:

it would place the Court in an invidious position if the Court were to hold that only such regulation of interstate trade as is in fact necessary for the protection of the community is consistent with the freedom ordained by $\mathrm{s}$ 92. The question whether a particular legislative enactment is a necessary or even a desirable solution to a particular problem is in large measure a political question best left for resolution to the political process. The resolution of that problem by the Court would require it to sit in judgment on the legislative decision, without having access to all the political considerations that played a part in the making of that decision, thereby giving a new and unacceptable dimension to the relationship between the Court and the legislature... 155

On this footing, it was accepted without question that South Australia did indeed have a litter problem and a limited supply of energy and that it was rational and legitimate for the State to take remedial action. Interestingly, the leading judgment's ready concession here did not appeal to Gaudron and McHugh JJ. In their separate reasons they rejected a posture of routine deference. ${ }^{156}$ In any case, it is enough to note that both judgments are alive to the need for a measure of deference in the section 92 context. ${ }^{157}$

factor in Gyles J's first instance decision in Sportodds Systems Pty Ltd v New South Wales (2003) 201 ALR 706. It may even have been a silent factor in Castlemaine, although the relevant prejudicial legislative debates were not adverted to in the judgments. However, where the asserted purpose is a benign one, as is more often the case, an objective purpose test will function better as a proxy for a subjectively-focused test.

153 See, generally, Australian Communist Party v Commonwealth (1951) 83 CLR 1. See also Nolan $v$ Minister for Immigration and Ethnic Affairs (1988) 165 CLR 178, 192 (Gaudron J). On the issue of striking a respectful tone in calibrating a test of constitutionality, see Jackson, above $n$ 77, 628-9.

154 On this general timidity, see Coper, Freedom of Interstate Trade, above n 10, 303.

155 (1990) 169 CLR 436, 473.

156 Ibid 480.

157 This is consistent with the 'general aversion of Australian judges to being seen to intrude on the political or legislative domain': Kirk, above $n 44,53$. Recent years have seen regular reiteration of this aversion in High Court judgments. For a very recent example, see APLA (2005) 219 ALR 403, 413-14 [31] (Gleeson CJ and Heydon J), 505-6 [418]-[419] (Hayne J). 


\section{(iv) Federal structural concerns and the dangers of defeasibility}

As noted earlier, over a lengthy period section 92 was conceptualised as a guarantee of an individual's right to trade. The Court, in Cole v Whitfield and later in Barley Marketing Board, has emphasised its departure from that theory. Section 92's benefits are now understood to be collective, with individuals benefiting only as a secondary and indirect consequence of section 92's operation. Moreover, as already outlined, this current understanding is grounded in federal structural concerns. Acceptance that section 92's role in the Constitution is, at least principally, a federal structural one has an important bearing upon the appropriateness of any section 92 test which treats the norm as defeasible. Specifically, as robust proportionality analysis is predicated upon the norms it governs being defeasible, we can say that that form of analysis is inappropriate if defeasibility itself seems undesirable or inappropriate.

This concept of defeasibility warrants a little more explanation here, as it differs in important ways from other balancing modalities seen in constitutional jurisprudence. Defeasibility, as I will use the term, is a quality shared by those constitutional norms that are explicitly treated as negotiable or dispensable; that is, they are inherently susceptible to override by competing social interests. Defeasible norms are, of necessity, applied by recourse to a form of reasoning sometimes called 'ad hoc balancing', in which the balancing that is undertaken is built into doctrinal principles as an integral and unavoidable step in the reasoning. ${ }^{158}$ In other words, a fresh and explicit balancing of competing imperatives is effectively demanded of courts in each and every case in which the relevant doctrinal principles are enlivened. Ad hoc balancing is, then, very different in nature from the 'categorical' or 'definitional' balancing of competing imperatives that courts may undertake at the level of doctrinal design when expounding and rationalising a new principle intended to govern a particular class of case into the future. ${ }^{159}$ In contexts where the High Court has embraced robust proportionality analysis, most notably in relation to the implied freedom of political communication, it has instituted a methodology of ad hoc balancing in keeping with the defeasible character of those norms. ${ }^{160}$

Yet in developing and applying doctrines underpinned by federal structural concerns, the High Court has generally shied away from defeasibility as a doctrinal feature - that is, it has preferred not to treat these constitutional limitations as defeasible by reference to competing interests. ${ }^{161}$ This preference ought to prove instructive in approaching section 92 . Given the paucity of textual pointers in section

158 Melville Nimmer, Nimmer on Freedom of Speech (1984) §§ 2.02-2.03; Louis Henkin, 'Infallibility under Law: Constitutional Balancing' (1978) 78 Columbia Law Review 1022; T Alexander Aleinikoff, 'Constitutional Law in the Age of Balancing' (1987) 96 Yale Law Journal 943, 948; Richard Fallon Jr, 'Foreword: Implementing the Constitution' (1997) 110 Harvard Law Review 54, 77-79.

159 This distinction is explained clearly, and translated to an Australian context, in Adrienne Stone, 'The Limits of Constitutional Text and Structure: Standards of Review and the Freedom of Political Communication' (1999) 23 Melbourne University Law Review 668.

160 Lange $v$ Australian Broadcasting Corporation (1997) 189 CLR 520, 561-2, 567. See also Mulholland $v$ Australian Electoral Commission (2004) 209 ALR 582.

161 My argument would be strengthened if I were able to claim that this preference did not manifest only in the realm of federal structural implications, but rather permeated all constitutional implications. However, as noted above, the implied freedom of political communication, as presently conceptualised, is clearly a defeasible principle. 
92, the most closely analogous doctrines underpinned by federal structural considerations are probably the implied limitations upon power. The Court's section 117 jurisprudence, while dealing with a limitation upon power underpinned by a federal structural rationale, is less helpful in that its interpretation is confined by clear text which is, moreover, explicitly focused upon the individual. ${ }^{162}$

The doctrine of state immunity, or 'Melbourne Corporation principle', 163 seems an especially fruitful basis for comparison and guidance in that its rationale, like that for section 92 , is to preserve the integrity of the federal political compact. ${ }^{164}$ In the case of the state immunity doctrine, the perceived danger is the erosion of the States' capacity to function as independent component polities within the federation. ${ }^{165}$ In the case of section 92, it is the erosion of the goodwill and restraint that sustain the federal compact. The state immunity doctrine has long been understood to involve an absolute imperative - absolute in the sense, at least, of not being defeasible by reference to competing interests. ${ }^{166}$ Specifically, the Constitution prohibits Commonwealth laws ${ }^{167}$ which undermine a State's capacity to function as an independent polity. ${ }^{168}$ There is no scope for setting off the interest in maintaining the federal compact, on the one hand, against other important interests like convenience and efficiency in government, or equal treatment as between the Crown and other legal subjects, on the other. As Gleeson CJ put it in Austin $v$ Commonwealth:

where the argument is that a federal law compromises the structural framework of the federal system, in such a way that the principle of federalism is offended, then the outcome of that argument cannot depend upon a comparative assessment of the governmental interests that are advanced or affected. ${ }^{169}$

According to the Constitution's internal logic, then, the federal structural imperative will be paramount, no matter what competing interests may exist. For this reason, the

162 In this respect s 117 is analogous to the 'intercourse' limb of s 92. As explained, the High Court has distinguished that limb from the trade and commerce limb and indicated that different principles underpin each, such that different tests are appropriate: Cole $v$ Whitfield (1992) 165 CLR 360, 388, 394.

163 In reference to the seminal case of Melbourne Corporation v Commonwealth (1947) 74 CLR 31.

164 See Amelia Simpson, 'State Immunity from Commonwealth Laws: Austin v Commonwealth and Dilemmas of Doctrinal Design' (2004) 32 University of Western Australia Law Review 44.

165 Melbourne Corporation v Commonwealth (1947) 74 CLR 31, 56 (Latham CJ), 66 (Rich J), 74 (Starke J), 82 (Dixon J); Re Australian Education Union; Ex parte Victoria (1995) 184 CLR 188, 227; Austin v Commonwealth (2003) 215 CLR 185, 217 (Gleeson CJ), 248 (Gaudron, Gummow and Hayne JJ), 278-9 (McHugh J), 301 (Kirby J).

166 While this is clearly the dominant view, there have been occasional indications to the contrary in the judgments in relevant cases. See, eg, Queensland Electricity Commission v Commonwealth (1985) 159 CLR 192, 239-40 (Brennan J).

167 It remains uncertain whether the limitation operates to constrain Commonwealth executive action, as well as legislative action. Some formulations of the Melbourne Corporation principle are suggestive of such a wider reach: see, eg, Melbourne Corporation $v$ Commonwealth (1947) 74 CLR 31, 75 (Starke J).

168 Austin v Commonwealth (2003) 215 CLR 185; Bayside City Council v Telstra Corporation Limited (2004) 216 CLR 595, 626. Where the impugned law is one of general application, the implied limitation may operate to compel a reading down in favour of the States rather than dictating wholesale invalidation. However, this does not negate the absolute nature of the implied prohibition, as the States' protection remains complete. 
idea of defeasibility as a basic feature of state immunity doctrine has not been countenanced.

Aspects of the High Court's emerging jurisprudence concerning federal judicial power, for which Chapter III of the Constitution provides, also emphasise the nondefeasible nature of implied prohibitions with federal structural foundations. A central and recurring theme of that jurisprudence has been 'the critical significance of Ch III for the maintenance of the federal compact.' 170 In Re Wakim; Ex parte McNally a majority of the Court found that an implied constitutional limitation, serving to protect the integrity of a separate federal judicial system, prevented the States from conferring jurisdiction upon federal courts. ${ }^{171}$ This conclusion depends upon an assumption that the Constitution requires, in many areas, a strict demarcation of powers and functions as between levels of government. ${ }^{172}$ Leaving aside the question of whether that view is necessary or preferable, ${ }^{173}$ it is clear that the demarcation envisioned was an absolute one, in the sense that its dictates are not defeasible in the face of countervailing interests and values. In Wakim, this meant that the considerable, and acknowledged, benefits of convenience flowing from a vesting of State jurisdiction in federal courts could not temper the application of the implied constitutional limitation. ${ }^{174}$ The tenor of the leading judgments suggests that the absolute nature of the limitation follows necessarily from federalism's status as the paramount principle infusing and undergirding the Constitution. 175

If section 92 is likewise understood as a federal structural protection, it makes sense that it also presents as a firm, unbending limitation upon power, rather than one which is negotiable or dispensable. To permit the federal structural interest that it protects to be traded off readily against other, competing, interests would be to deny the essential paramountcy of the former. ${ }^{176}$ Leaving aside meta-constitutional notions of revolution and so on, ${ }^{177}$ a written, entrenched Constitution treating its own preservation as a good

170 Kruger $v$ Commonwealth (1997) 190 CLR 1, 122 (Gaudron J), citing Wilson $v$ Minister for Aboriginal and Torres Strait Islander Affairs (1996) 189 CLR 1. See also Kable v Director of Public Prosecutions (NSW) (1996) 189 CLR 51.

171 (1999) 198 CLR 511, 540 (Gleeson CJ), 546 (Gaudron J), 558 (McHugh J), 575 (Gummow and Hayne JJ), 626 (Callinan J) ('Wakim').

172 Graeme Hill, 'Revisiting Wakim and Hughes: The Distinct Demands of Federalism' (2002) 13 Public Law Review 205, 215-7.

173 Ibid 217-26.

174 (1999) 198 CLR 511, 540 (Gleeson CJ), 548, 554 (McHugh J), 569 (Gummow and Hayne JJ), 625 (Callinan J). See also Re Woolley; Ex parte Applicants M276/2003 (2004) 210 ALR 369, 392 (McHugh J).

175 Wakim (1999) 198 CLR 511, 556-7 (McHugh J), 574 (Gummow and Hayne JJ).

176 This may have been what McHugh J was getting at when he used s 92 as an example of the immovability of the Constitution's dictates in Wakim, ibid 556:

Try as they might, for example, the States and the Commonwealth cannot defeat the operation of s 92 of the Constitution, no matter how burdensome or inconvenient its application to government activity may be. That is because s 92 withdraws power from the States and the Commonwealth over the area where it operates.

177 I would include here those extreme and unusual circumstances - variations on the theme of imminent danger - that have at times inspired courts to dispense with, or navigate around, normally iron-clad constitutional principles. See, eg, the abnormally deferential 
having only relative value seems paradoxical. If indeed the notion of defeasibility works against the fundamental rationale underpinning section 92 , this must surely lessen the appeal of any section 92 test premised upon defeasibility, including the robust proportionality model considered in Section 3.

Importantly, to find that defeasibility, and its accompanying evaluative balancing of interests, is an inappropriate feature of section 92 doctrine does not rule out some sort of balancing at the prior level of doctrinal design. ${ }^{178}$ Consideration of the likely consequences of shaping doctrine in this direction or that, or carving out exceptions, has become a generally accepted part of the process of judicial decision-making, including constitutional adjudication. ${ }^{179}$ Indeed, such balancing ought to prove pivotal in addressing the next question that arises once it has been determined that section 92 cannot be constrained sensibly by a principle of defeasibility. That question is whether a requirement of improper legislative purpose should be adopted, to achieve the exclusion of unintended protectionist discrimination from section 92's purview.

Without such a touchstone of improper purpose, and in circumstances where defeasibility-based constraints were considered off-limits, the section 92 norm would burgeon beyond anyone's conception of its acceptable scope and reach. It would, under those conditions, invalidate all laws having an unintended protectionist effect upon interstate trade, no matter what desirable goals those laws may achieve. ${ }^{180}$ Such an untrammelled conception of free trade has never commended itself to the High Court. ${ }^{181}$

In deciding, then, whether or not to adopt a touchstone of improper purpose in the section 92 context, an important consideration must be the need for legitimate regulation of interstate trade and commerce. Indeed, the High Court emphasised this very factor in Cole $v$ Whitfield when weighing the case for doctrinal overhaul of section 92. ${ }^{82}$ While a norm confined by reference to purpose does have the potential to invalidate some laws having desirable regulatory effects, that potential is greatly lessened when those effects inform what will typically operate as an objective purpose test. ${ }^{183}$ In circumstances where a doctrine reliant upon defeasibility seems undesirable, the policy considerations that press for a confinement of non-discrimination norms can find expression in a purpose-focused test.

stance of the High Court in assessing the reach of the Commonwealth's s 51(xi) defence power during wartime: Farey $v$ Burvett (1916) 21 CLR 433.

178 This latter kind of balancing modality was referred to above using the American terminology of 'categorical' or 'definitional' balancing.

179 See, eg, Aleinikoff, above n 158, 1001; Sir Anthony Mason, 'The Role of a Constitutional Court in a Federation: A Comparison of the Australian and the United States Experience' (1986) 16 Federal Law Review 1, 5; Justice J J Doyle, 'Judicial Law Making - Is Honesty the Best Policy?' (1995) 17 Adelaide Law Review 161; Zines, above n 1, 445.

180 I am assuming here that making legal form the principal touchstone is out of the question, in light of the High Court's unequivocal rejection of that option in Cole $v$ Whitfield. See the discussion in Section 1, above.

181 That there must be limits to $\mathrm{s} 92$ 's reach is one of the few aspects of $\mathrm{s} 92$ jurisprudence on which there has been enduring agreement. See, eg, W \& A McArthur Ltd v Queensland (1920) 28 CLR 530, 567-8 (Gavan Duffy J).

182 (1988) 165 CLR 360, 403.

183 See the discussion at $n$ 152, above. 


\section{(v) Distinguishing other free trade models}

My discussion to this point suggests that an anti-protectionism norm understood to be grounded principally in economic objectives is likely to extend to unintended protectionist discrimination. Where the rationale underpinning a non-discrimination norm is the pursuit of economic wellbeing it makes good sense that unintended protectionist discrimination be caught within the norm's scope, for the relevant harm is not lessened by the absence of intent. However, it will also likely be conceded that some burdening of incoming trade is unavoidable if governments are to retain the ability to regulate effectively in the interests of health, safety, the environment, and other non-economic goals. It is not surprising, then, to find anti-protectionist norms grounded in economic interests to be constrained by reference to principles of defeasibility. The free trade norms administered by the European Court of Justice afford useful examples. ${ }^{184}$ Those principles are grounded explicitly in a desire to secure the economic benefits of free trade. ${ }^{185}$ The free trade provisions of the Treaty are constructed explicitly around the idea of defeasibility, precise grounds for which are set out in the text. ${ }^{186}$ There is an additional, judicially supplied, avenue for defeasibility in certain other situations. ${ }^{187}$

Some commentary on the High Court's approach to section 92 has praised the European free trade jurisprudence and urged the High Court to take guidance from it. In particular, commentators have suggested that the central principle of protectionism, which serves to narrow the scope of the section 92 norm, should be jettisoned. ${ }^{188}$ That principle is said to inhibit closer alignment with the European model and, more fundamentally, to hamstring section 92 in its capacity to secure the economic benefits of free trade. This view not only reflects the widespread misunderstanding about the rationale underpinning section 92 but also points to a further reason why the High Court should favour a touchstone of improper purpose as the centrepiece of its section 92 doctrine.

184 Treaty Establishing the European Community, opened for signature 25 March 1957, 298 UNTS 11, arts 28 and 30 (entered into force 1 January 1958) ('EC Treaty'). The Agreements administered by the World Trade Organization further illustrate the point, although these have not been a focus for comparison with s 92 in the Australian scholarship.

185 Article 2 of the EC Treaty confirms that the Treaty's principal purpose is to promote economic development. As the EC Treaty provisions pursue agreed supranational interests, any political utility they may have is similarly supranational. While European political arrangements are becoming more analogous with those of federal nation states, the EC free trade regime remains grounded in the prior paradigm of economic development and integration: see Peter Stirk and David Weigall (eds), The Origins and Development of European Integration: A Reader and Commentary (1999).

EC Treaty, art 30 states:

The provisions of [Article 28] shall not preclude prohibitions or restrictions on imports, exports or goods in transit justified on grounds of public morality, public policy or public security; the protection of health and life of humans, animals or plants; the protection of national treasures possessing artistic, historic or archaeological value; or the protection of industrial and commercial property.

187 The so-called 'rule of reason': see Procureur du Roi v Benoit \& Gustave Dassonville [1974] ECR 837, 852; Rewe-Zentral AG v Bundesmonopolverwaltung für Branntwein (Cassis de Dijon Case) [1979] ECR 649, 662.

188 See, eg, Staker, above n 60, 342-5; Villalta Puig, above n 60, 649-50. 
The concept of protectionism features prominently in the High Court's decision in Cole $v$ Whitfield. As was explained in Section 1, the Court's historical analysis revealed protectionism to be the mischief to which section 92 was directed. ${ }^{189}$ Further, the Court found that the contemporary meaning of 'free trade' was 'an absence of protectionism', rather than some more general notion of minimising impediments to the free movement of goods. ${ }^{190}$ Thus, the element of local advantage was considered critical to the mischief which section 92 combats, both by the framers and by the Cole Court. Given the pivotal role played by this element of protectionism in the re-invention of section 92, the Court would not now dispense with it lightly. It can be assumed, moreover, that the Cole Court was familiar with the European Court's jurisprudence and was well aware of the way in which a requirement of protectionism would constrain the scope of the section 92 norm. ${ }^{191}$ Critics of the High Court's emphasis upon protectionism are asking a lot in suggesting that the Court abandon that principle and reinvent section 92 as a provision with a predominantly economic rationale.

In any case, the significance of comparisons with the European jurisprudence is not that they induce misguided criticism. Rather, they highlight the fact that protectionism has been given particular prominence within the new section 92 jurisprudence by a Court doubtless aware of that principle's absence from free trade norms operating in some other jurisdictions and settings. This suggests that the Cole Court subscribed consciously to a federal structural rationale rather than, or at least in priority to, a rationale grounded in economic efficiency. As I explained earlier in this Section, if it is accepted that section 92's role is a federal structural one, there is good reason to avoid defeasibility-based approaches to containing the norm's reach.

\section{(vi) Purpose-focused tests, fact-finding and judicial competence}

In comparing the merits of alternative doctrinal paths, any number of considerations might be brought to bear. There is an abundant literature on the relative merits of purely intention- or purpose-focused tests and those instead conceding intrinsic significance to effects, both in a constitutional context and more generally. ${ }^{192}$ It is beyond the scope of this article to canvass, even superficially, all of the arguments that can be made. ${ }^{193}$ I will instead focus upon one criterion that has featured prominently

189 (1988) 165 CLR 360, 391-3.

190 Ibid 392

191 Other High Court decisions of similar vintage to Cole $v$ Whitfield reveal an interest in and familiarity with European jurisprudence spanning a range of legal fields. See, eg, Queensland Wire Industries Pty Ltd v Broken Hill Proprietary Co Ltd (1989) 167 CLR 177, 188 (Mason CJ and Wilson J); Street v Queensland Bar Association (1989) 168 CLR 461, 571 (Gaudron J); Attorney-General (NT) v Maurice (1987) 161 CLR 475, 490 (Deane J).

192 See, eg, Alexander Bickel, The Least Dangerous Branch (1962); John Hart Ely, 'Legislative and Administrative Motivation in Constitutional Law' (1970) 79 Yale Law Journal 1205; John Hart Ely, Democracy and Distrust (1980); Greenawalt, Statutory Interpretation, above n 121, chs VIII to XI. See also the symposium articles in (1978) 15 San Diego Law Review, in particular: Paul Brest, 'Reflections on Motive Review', 1141; J Morris Clark, 'Legislative Motivation and Fundamental Rights in Constitutional Law', 953; Kenneth Karst, 'The Costs of Motive-Centered Inquiry', 1163.

193 While the criterion of judicial legitimacy could be invoked as a basis for preferring one doctrinal course over another, that multi-faceted debate with its many levels of contestation would, as noted earlier, require a separate article. It suffices to note here that individual 
in the scholarly treatment of section 92 . That criterion can be described loosely as judicial competence. In particular, some critics charge that the modern section 92 jurisprudence involves the High Court in assessments of complex economic matters for which it is ill-equipped, both procedurally and in terms of expertise. ${ }^{194}$ If these difficulties are conceded, they may provide a further basis for preferring a touchstone of improper legislative purpose. While neither a purpose-focused approach to section 92 nor the alternative of a robust proportionality approach is entirely immune from competency-based objections, I will argue that a purpose-focused approach is the least vulnerable.

Inquiry into a law's actual effects raises two practical problems in the section 92 context, both stemming from the often complex and technical nature of economic factfinding. ${ }^{195}$ The first problem is one of expertise. Specifically, the Court is constituted by judges whose principal training lies in the law rather than the highly specialised and conceptually far-removed discipline of economics. ${ }^{196}$ Yet, in such matters as identifying a market and determining the existence of a market advantage, a considerable level of economic expertise is required. 197 Chief Justice Mason acknowledged this difficulty openly during argument in Barley Marketing Board. ${ }^{198}$ While being plied with unsupported assertions about the economics of commodity pooling and marketing schemes, Mason CJ likened the judicial task to 'stumbling round in the dark.' ${ }^{199}$

The second practical problem attending fact-finding in the section 92 context is procedural. The High Court is, perhaps partly through its own inaction, ${ }^{200}$ poorly equipped to undertake fact finding in the course of constitutional litigation. ${ }^{201}$ Beyond

judges are unlikely to be persuaded easily that their own views are flawed. It also appears that the High Court has grown less comfortable with evaluative balancing in the constitutional context since the leading s 92 cases were decided: Langer $v$ Commonwealth (1996) 186 CLR 302, 318 (Brennan CJ), 334 (Toohey and Gaudron JJ); Leask (1996) 187 CLR 579, 602 (Dawson J); Kruger v Commonwealth (1997) 190 CLR 1, 128 (Gaudron J).

194 See Andrew Bell, 'Section 92, Factual Discrimination and the High Court' (1991) 20 Federal Law Review 240; Rose, above n 1, 346; Kirk, above n 44, 53-4, 56.

195 For a discussion of the High Court's own competence-based concerns about fact-finding, see Kenny, above n 60, 163; Bell, above n 194.

196 See, generally, Colin Diver, 'Sound Governance and Sound Law' (1991) 89 Michigan Law Review 1436. See also Kirk, above n 44, 57. Kirk notes that even the European Courts with their explicitly effects-based balancing jurisprudence are deferential where matters of complex economic fact are implicated. Presumably, that deference flows from recognition of the competence concerns thus raised. Staker, above n 60, 344-5 and Bell, above n 194, 245-9 also see this expertise-related difficulty as likely to plague fact-finding efforts in the s 92 context.

197 Bell, above n 194, 246, noting the parallel with Part IV of the Trade Practices Act 1974 (Cth) and the acknowledged dependence on expertise in that context.

198 Transcript of Proceedings, Barley Marketing Board (High Court of Australia, Mason CJ, 5-6, 199 June

200 Kenny, above n 60, 149ff; Zines, above n 1, 474.

201 Coper, 'Section 92 of the Australian Constitution', above n 1, 146-7; Bell, above n 194, 247;

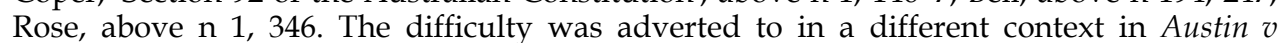
Commonwealth (2003) 215 CLR 185, 249; see Graeme Hill, 'Austin v Commonwealth: Discrimination and the Melbourne Corporation Doctrine' (2003) 14 Public Law Review 80, 83. 
the limited range of facts that may be taken on judicial notice, the Court depends entirely upon such evidence as the parties choose to submit. ${ }^{202}$ While in Cole $v$ Whitfield and Castlemaine the parties were in substantial agreement upon critical matters of fact, ${ }^{203}$ the Court cannot count on this in every section 92 case. As was conceded in Cole, much of the Court's fact-finding in section 92 litigation ultimately will have to rest upon nothing more than 'judicial impression'. ${ }^{204}$ Moreover, reliance upon the parties to furnish facts may sometimes mean that the wider range of interests and concerns informing the enacting legislature goes unnoticed in the Court's deliberations. ${ }^{205}$

These acknowledged difficulties have prompted some commentators to endorse the solution proposed by the 1988 Constitutional Commission, being a reinvigoration of the Inter-State Commission. 206 This body, provided for in section 101 of the Constitution, could be given responsibility for the fact finding in section 92 cases involving technical and voluminous economic evidence. The Commission's potential involvement has been considered carefully elsewhere. ${ }^{207}$ Rather than revisit it here, I will simply note the unlikelihood that this proposal will be heeded by the Commonwealth anytime soon. The Commission's last incarnation, during the 1980s, came to an abrupt and unceremonious end when the Commonwealth decided that its usefulness had passed. ${ }^{208}$ Little has changed in the meantime to suggest the determinative political considerations might play differently today. Realistically, any amelioration in the fact-finding problems attending section 92 will need to proceed at the Court's initiative, via the medium of doctrinal choice. ${ }^{209}$

I have noted already that even if the Court were to accept legislative purpose as the ultimate touchstone of invalidity within its section 92 doctrine, it would frequently still need to consider an impugned law's actual effects. This is because those effects will

202 This dependency was a notable source of frustration for the Court on earlier understandings of section 92 that revolved around factual determinations: see Sawer, above $\mathrm{n} 10,193$

203 In both cases, the parties submitted joint statements of agreed facts. In Cole, this statement virtually eliminated the scope for factual dispute and with it the need for judicial factfinding. In Castlemaine, South Australia made concessions during argument that reduced greatly the need for judicial fact-finding.

204 (1988) 165 CLR 360, 408.

205 The inevitability of this neglect has long been understood by the Court and invoked to justify its reluctance to engage in factual inquiry. See, for instance, Jumbunna Coal Mine, No Liability v Victorian Coal Miners' Association (1908) 6 CLR 309, 376 (Isaacs J). While courts are sometimes prepared to undertake their own independent fact-finding, that course is not pursued lightly given the 'obvious dangers' attending it in an adversarial system: Sportodds (2003) 133 FCR 63, 82. See also Gerhardy v Brown (1985) 159 CLR 70, 141-2 (Brennan J).

206 Constitutional Commission, Final Report of the Constitutional Commission (1988) 838-45.

207 Ibid; Michael Coper, 'The Second Coming of the Fourth Arm: The Role and Functions of the Inter-State Commission' (1989) 63 Australian Law Journal 731; Cheryl Saunders, 'Hallmarks of Australian Federalism: Securing Free Trade and a Common Market' in C Lloyd Brown-John (ed), Federal-type Solutions and European Integration (1993) 307; Bell, above n 194.

208 Industry Commission Act 1989 (Cth) s 48; Coper, 'The Second Coming', above n 207.

209 Another mooted alternative - remittal to a single High Court judge or a lower court seems merely to shift, rather than address, the problems of limited judicial time and expertise. See Bell, above n 194, 250-1. 
often be the most reliable objective indicators of purpose. However, that kind of familiar 210 instrumental inquiry into effects seems in practice to permit of a more coarse-grained analysis, when compared with the detailed and finely calibrated treatment that might be expected where a law's effects are themselves the touchstone of its validity. 211

The claim that purpose-focused tests are less dependent upon factual evidence is often advanced as though self-evident. Where explanation is attempted, it will typically be in terms of the supposedly lesser number of distinct 'interests' to be weighed under a purpose test, ${ }^{212}$ or the more natural affinity that those tests may have with the kinds of 'presumptions' that can provide cover for shallow factual inquiry. ${ }^{213}$ Realistically, though, the degree of rigour brought to an assessment of factual evidence is unlikely to be a simple function of whether the prevailing test is geared to purpose or effects. ${ }^{214}$ It is, at base, going to reflect a quite separate constitutional policy choice as to whether particular kinds of laws should be under- or over-invalidated. It may also reflect judicial idiosyncrasies. Some judges, by disposition or through particular interest, will bring great rigour to a purpose-focused test, whereas others may make fairly slapshod use of an effects-focused test. Judges will also differ in their preparedness to make do with whatever evidence the parties have furnished, in instances where that evidence seems, strictly speaking, incomplete or inadequate. ${ }^{215}$

Nevertheless, even if its logic is uncertain, the idea that purpose-focused inquiry places lesser demands upon a court's fact-finding capacities does seem to represent a fairly widespread judicial intuition in the context of anti-protectionist norms, at least in cases involving facially neutral laws. ${ }^{216}$ This intuition is evident in the way in which anti-protectionist non-discrimination norms are administered in other legal systems. Where such norms are understood to encompass both purposeful discrimination and unintended effects discrimination, a preference commonly develops for investigating the former possibility first, so as to circumvent the latter inquiry wherever possible. This sequential or 'tiered' approach is evident in the European free-trade jurisprudence, and indeed may be implicit in European proportionality jurisprudence

210 The Court already has considerable experience in undertaking this task, which is a staple of analysis in contract law, criminal law, and statutory interpretation.

211 As to the supposedly greater fact-dependency of an effects-focused test, see Sportodds (2003) 133 FCR 63, 66, 77-8.

212 Fried, above n 140, 58-9; Aleinikoff, above n 158, 977-8; Richard Fallon, Implementing the Constitution (2001) 86; Ashutosh Bhagwat, 'Purpose Scrutiny in Constitutional Analysis' (1997) 85 California Law Review 297, 322; Donald Regan, 'Judicial Review of Member-state Regulation of Trade within a Federal or Quasi-federal System' (2001) 99 Michigan Law Review 1853, 1892-3.

213 Fried, above n 140, 63-4; Fallon above n 212, 95-6; Bhagwat, above n 212, 322-3, 354.

214 See, eg, Jed Rubenfeld, 'Affirmative Action' (1997) 107 Yale Law Journal 427.

215 This criticism has been levelled in relation to Cole $v$ Whitfield: see Coper, 'Section 92 and the Future of Agricultural Marketing', above n 27.

216 The same intuition may not hold where the question is whether a facially discriminatory law is protectionist in purpose or effect. However, strong presumptions of invalidity, typical in these settings, may serve to reduce the dependence upon factual evidence. Different views as to the merits of such a presumption may have been a factor in the disagreement between the majority and minority in Bath $v$ Alston Holdings Pty Ltd (1988) 165 CLR 411. 
more generally. ${ }^{217}$ It also features in the administration of other multilateral free-trade norms, including the GATT and NAFTA. ${ }^{218}$ Even the notoriously unclear United States dormant commerce clause jurisprudence has been said to involve the same preference for purpose-focused analysis as an initial line of inquiry. ${ }^{219}$ Closer to home, it is also an intuition which finds some resonance in the section 92 decisions and secondary literature. 220

This pattern suggests that judges at least believe that purpose-focused inquiry places less strain upon their institutional competencies. If so, a commitment, in the section 92 context, to reviewing a law's effects only as a basis for inferring improper legislative purpose would seem to offer a practical means of addressing competency concerns.

One final issue concerning fact-finding warrants mention here, though it is not really a question of 'judicial competence' but more a matter of doctrinal design. It springs from one of the enduring tensions facing courts in the formulation and refinement of tests, specifically, the tension between doctrinal stability, on the one hand, and the capacity to tailor decisions to real world particularities, on the other. ${ }^{221}$ Whatever the virtues of fact-responsive doctrine, these inevitably come at the price of greater volatility. Where decisions are calibrated to particular facts - in the section 92 context, facts as to the functioning of a market and the behaviour of its participants any subsequent change in those facts invites, at least in principle, reconsideration of the decision.

In Cole $v$ Whitfield the High Court may have been acknowledging the need to loosen the factual tether, insisting that matters of impression would inevitably play some role in its reasoning. ${ }^{222}$ This may, in part, represent a concession that decisions could not be based exclusively upon a particular confluence of facts, an element of abstraction being necessary to stabilise decisions. In any case, whether or not the Court was conscious of it, passing factual detail through the filter of 'impression' effectively holds that detail at arm's length from the resulting decision. This distancing probably helps to dissuade litigants who might otherwise return again and again to the Court, armed with new facts and seeking reconsideration of matters already decided. More importantly, it

217 Gráinne de Búrca, 'Unpacking the Concept of Discrimination in EC and International Trade Law' in Catherine Barnard and Joanne Scott (eds), The Law of the Single European Market: Unpacking the Premises (2002) 181, 191-2; Kirk, above n 44, 5-7, 62; Villalta Puig, above n 60.

218 Tiered analysis, with an initial focus upon purpose, features in GATT and NAFTA reviews of facially neutral environmental measures: see Bradly Condon, 'Reconciling Trade and Environment: A Legal Analysis of European and North American Approaches' (2000) 8 Cardozo Journal of International and Comparative Law 1, 12-15.

219 See Michael Lawrence, 'Towards a More Coherent Dormant Commerce Clause: A Proposed Unitary Framework' (1998) 21 Harvard Journal of Law and Public Policy 395, 416-22.

220 Coper, 'Section 92 of the Australian Constitution', above n 1, 142; Rose, above n 1, 346. The intuition also seems implicit in the decision tree model of section 92 jurisprudence, discussed in Section 1(iii) above.

221 See Australian Textiles Pty Ltd v Commonwealth (1945) 71 CLR 161, 181; Zines, above n 1, 475-6.

222 (1988) 165 CLR 360, 407-9. 
ought to dissuade States from trying to resuscitate, on the strength of modest shifts in facts, laws previously found unconstitutional. ${ }^{223}$

Sawer has suggested that the Court was forced to contrive this distancing during those pre-Cole periods when section 92 analysis took an intrinsic interest in a law's effects. 224 Faced with litigants seeking to reopen decided cases based on claimed factual shifts, the Court of necessity began to abstract its analysis, calibrating it more loosely to the undergirding facts. This contrivance would likely tempt the Court again were it to pin its section 92 doctrine on an intrinsic interest in effects, as in the proportionality-based understanding examined in Section 3. However, on the looser, instrumental, use of facts that I have attributed to a purpose-focused test, the filtering of facts through a lens of judicial impression becomes a natural and readily defensible component of the approach.

(vii) Summary: principle and practicality favour a focus upon improper legislative purpose

This Section has made a number of arguments in favour of a section 92 doctrine incorporating a touchstone of improper legislative purpose - that is, a doctrine in which (1) a showing of improper purpose is a necessary condition for invalidity, such that (2) the norm does not extend to instances of unintentional protectionist discrimination. I have asserted that that approach is preferable to the main competing understanding of section 92 centred upon a robust proportionality analysis. That competing understanding (1) relies upon a concept of defeasibility to constrain section 92's reach and (2) employs an evaluative balancing test to invalidate some instances of unintentional protectionist discrimination. The considerations explored in this Section - the rationale underpinning section 92 and its apparent dictates; key doctrinal principles accepted in analogous areas; a contrast with other systems of free trade jurisprudence; and the acknowledged practical difficulties that may attend application of section 92 - offer the High Court several compelling bases for opting to ground section 92 by reference to legislative purpose.

As mentioned in the Introduction, other recent scholarship on section 92 has shown interest in how the norm would, or should, apply in hitherto unexplored contexts. Among the most widely canvassed of these frontier issues are the Cole test's application to Commonwealth laws, its appropriateness in the case of export controls, and its effectiveness to constrain misuse of administrative discretion. I have chosen to sidestep these issues, as their consideration would not much advance my argument. Nor would it, I think, be useful to explore my position in the context of factual scenarios taken from additional cases, or imaginable cases. As the analysis in Sections 2 and 3 reveals, the distinction between a purpose-focused section 92 doctrine and one constructed around effects-plus-defeasibility is decidedly minimal, in terms of the

223 For instance, if South Australia were to procure new data on the relative rates of bottle return and discover some change in the public's behaviour, it might feel justified in reintroducing the differential refund rates found unconstitutional in Castlemaine. It would then fall to an affected party to take the matter before the High Court to contest the significance of the new data. If such testing of an earlier decision's tipping point became the norm, the States would doubtless be advantaged by their status as experienced and well resourced constitutional litigants. 
concrete results we might expect from each. ${ }^{225}$ They are, essentially, different paths to the same conclusion. The importance of the distinction lies instead in the fact that one account is more successful than the other in justifying those concrete results and embedding the modern section 92 jurisprudence securely in the wider corpus of constitutional doctrine. To the extent, then, that my analysis here has been abstract and theoretical, it has been so out of necessity rather than neglect.

\section{CONCLUSION}

This article has set out to identify and analyse a significant loose end attending the High Court's treatment of section 92 of the Constitution. In conceiving of section 92 as a non-discrimination norm, the High Court's modern section 92 jurisprudence must incorporate appropriate principles to constrain the norm's reach. Some delimiting principles have been articulated clearly in the cases. However, the identity of one further principle remains unclear.

As to this shrouded principle, I have contended that the cases do not clearly support either of the two main contenders described in existing scholarship. On the assumption that the choice has yet to be made, I have explained why the Court ought to favour a purpose-focused principle over one that combines elements of defeasibility and evaluative balancing. Considerations of doctrinal principle and practicality, explored in Section 4, suggest that purpose is the better touchstone. In particular, an emphasis on improper purpose represents a good fit with section 92's history and rationale and responds credibly to standard concerns regarding the Court's capacity to administer the norm effectively.

225 The only cases in which different results seem a distinct possibility are those where limited and fairly general factual evidence creates a different impression regarding the legitimacy of some legislative measure than does a much more detailed factual inquiry. Bath $v$ Alston Holdings Pty Ltd was perhaps a case of this type. 